\title{
Sea and Lake Breezes: A Review of Numerical Studies
}

\author{
Erik T. Crosman • John D. Horel
}

Received: 1 September 2009 / Accepted: 7 June 2010 / Published online: 26 June 2010

(C) The Author(s) 2010. This article is published with open access at Springerlink.com

\begin{abstract}
Numerical studies of sea and lake breezes are reviewed. The modelled dependence of sea-breeze and lake-breeze characteristics on the land surface sensible heat flux, ambient geostrophic wind, atmospheric stability and moisture, water body dimensions, terrain height and slope, Coriolis parameter, surface roughness length, and shoreline curvature is discussed. Consensus results on the influence of these geophysical variables on sea and lake breezes are synthesized as well as current gaps in our understanding. A brief history of numerical modelling, an overview of recent high-resolution simulations, and suggestions for future research related to sea and lake breezes are also presented. The results of this survey are intended to be a resource for numerical modelling, coastal air quality, and wind power studies.
\end{abstract}

Keywords Coastal meteorology $\cdot$ Lake breeze - Sea breeze - Sea-breeze modelling · Thermally-driven circulation

\section{Introduction}

Sea, gulf, lake, and river breezes are local circulations driven by differential heating between land and water. The basic dynamics and properties of these thermally-driven systems, hereafter referred to collectively as sea breezes (SB), have been studied extensively since the 1950s and are well understood (Simpson 1994; Miller et al. 2003). Sea breezes are of interest because of their ubiquity around the world, their recurring and well-defined features that lend themselves to examination using a variety of analytic, observational, and numerical approaches, and their societal impacts. For example, land-use changes and rapid population growth in coastal regions (with projections of $75 \%$ of the world's population to be located in those areas by 2030) may lead to a significant degradation of coastal air quality in many

E. T. Crosman $(\bowtie) \cdot$ J. D. Horel

Department of Atmospheric Sciences, University of Utah, 135 S 1460 E Room 819 WBB, Salt Lake City, UT 84112-0110, USA

e-mail: erik.crosman@utah.edu 


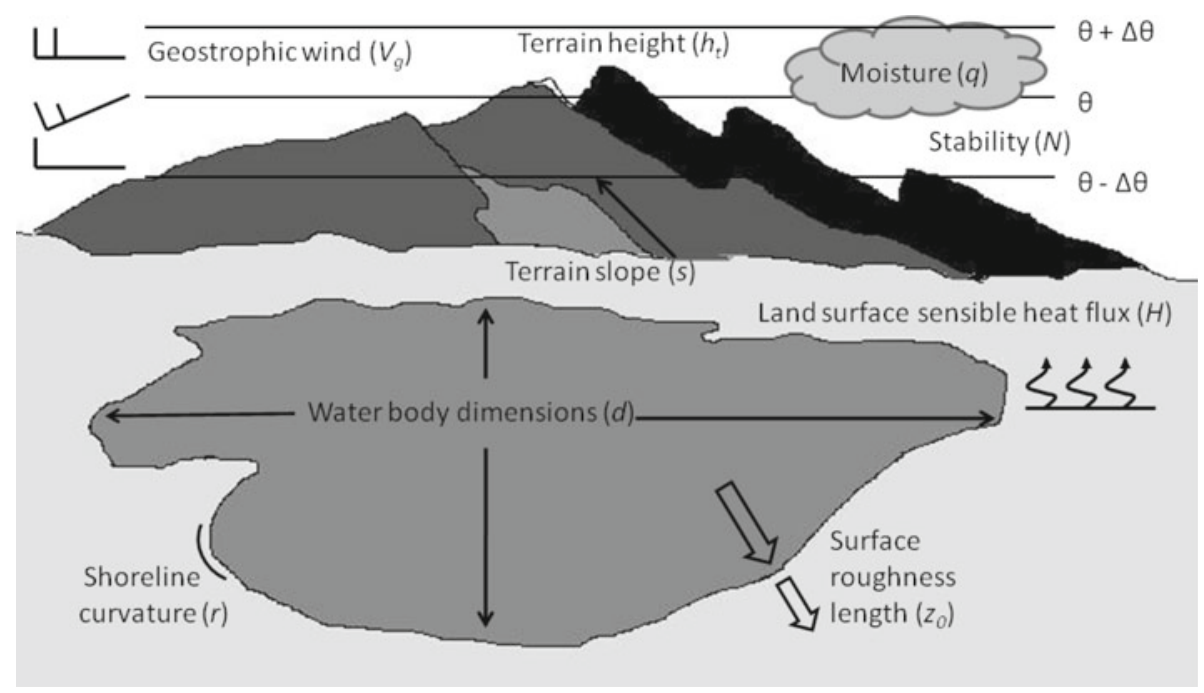

Fig. 1 Geophysical variables that control sea and lake breezes (Coriolis parameter $f$ not shown)

areas, with that degradation modulated by sea breezes (Hinrichsen 1999; Levy et al. 2008, 2009).

Although the overall structure, lifecycle, and forecasting of sea breezes have been reviewed extensively (e.g., Atkinson 1981; Pielke and Segal 1986; Abbs and Physick 1992; Simpson 1994; Segal et al. 1997; Miller et al. 2003), there has not been a review dedicated to the results from over 50 years of numerical modelling of sea breezes. The main focus of our survey concerns the modelled dependence of sea breezes on ten geophysical variables: the land surface sensible heat flux ( $H$, which establishes the land-sea temperature difference), ambient geostrophic wind $\left(V_{g}\right)$, atmospheric stability $(N)$, atmospheric moisture $(q)$, water body dimensions $(d)$, terrain height $\left(h_{t}\right)$, terrain slope $(s)$, Coriolis parameter $(f)$, surface aerodynamic roughness length $\left(z_{o}\right)$, and shoreline curvature $(r)$ (Fig. 1). Four of these variables vary significantly over time at a given location as a function of season, soil moisture content, and atmospheric state $\left(H, V_{g}, N\right.$, and $\left.q\right)$ while the remaining six are largely temporally invariant at any given location $\left(d, h_{t}, s, f, z_{o}\right.$, and $\left.r\right)$.

The spatial and temporal scales and quasi-regularity of sea breezes have provided a modelling framework for performing sensitivity experiments in which one or more variables are perturbed. The effects of the variables on the characteristics of sea breezes are discussed in terms of four widely-used measures of thermally-driven circulation intensity: the horizontal $(l)$ and vertical $(h)$ length scales and the horizontal $(u)$ and vertical $(w)$ wind speed scales (Fig. 2). The maximum onshore penetration distance of the sea-breeze front (SBF) is reflected in $l$. By convention $h$ represents the depth and $u$ the speed of the onshore low-level sea-breeze flow near the coastline. The depth of the sea-breeze gravity current as it passes over a heated land surface (Fig. 2) deepens nonlinearly with increasing distance inland due to boundary-layer convection (Garratt et al. 1990; Miller et al. 2003). The maximum upward vertical velocities observed in the region of the sea-breeze front are represented in $w$. The magnitude of $l, h, u$ and $w$ and other characteristics of sea breezes are time-varying quantities that typically increase (decrease) during the strengthening (weakening) phase of the 


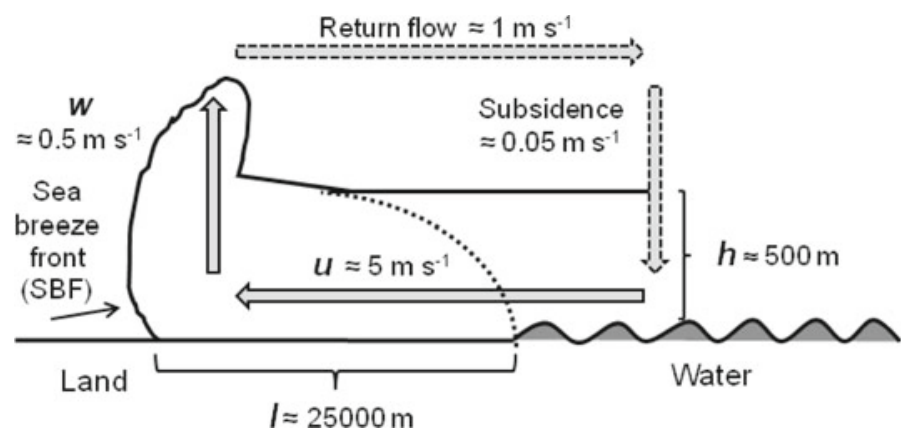

Fig. 2 Schematic illustration of a sea-breeze system and characteristic values of the horizontal $(l)$ and vertical $(h)$ length scales and the horizontal $(u)$ and vertical $(w)$ speed scales. Regions below the solid line represent the cool gravity current associated with sea breezes

sea-breeze lifecycle. In this review, maximum values of $l, h, u$ and $w$ obtained in mid to late afternoon are emphasized.

As should be expected, there has been no previous summary of the dependence of seabreeze speed and depth scales on the ten geophysical variables. Hence, our goal is to piece together the results from, and the agreement between, the many numerical studies. A limited review of observational studies is also included to ascertain the realism of the numerical simulations. Gaps in our understanding and recommendations for future research are also presented.

Although we believe ours is the most thorough review of numerical studies of sea breezes to date, it is far from comprehensive. The following topics are not extensively discussed: pollutant dispersion models (Clappier et al. 2000; Melas et al. 2006), land-surface models (Cheng and Byun 2008), linear and analytical models (Rotunno 1983; Niino 1987; Dalu and Pielke 1989; Qian et al. 2009; Drobinski and Dubos 2009), laboratory experiments (Simpson 1997; Cenedese et al. 2000; Hara et al. 2009), land breezes (Buckley and Kurzeja 1997), and convective internal boundary-layer growth (Garratt et al. 1990; Kuwagata et al. 1994; Levitin and Kambezidis 1997; Liu et al. 2001; Miller et al. 2003).

\section{Numerical Studies of Sea Breezes}

\subsection{History}

Numerical simulations of sea breezes require solving the equations of motion for the conservation of mass, momentum, and energy. Model physics (e.g., surface processes, radiation, latent heating, and turbulent diffusion of heat, moisture, and momentum) and model dynamics (horizontal advection, vertical acceleration, Coriolis effects, density changes, and timedependence) must be adequately resolved to obtain a realistic simulation (Avissar et al. 1990). Increasingly sophisticated treatment of both model dynamics and physics has occurred over the past fifty years. Table 1 summarizes the evolution of model physics, horizontal resolution, and dimension that parallels the increase in computational speed. The earliest hydrostatic models used simple boundary-layer schemes and neglected moisture, latent heating, radiation, and land-surface parametrisations. Some later models included radiation, moisture and latent heating, with increasingly sophisticated schemes for surface heating and the turbulent 
Table 1 Numerical modelling studies published between 1955 and 2010 that have been reviewed as part of this study

\begin{tabular}{|c|c|c|c|c|}
\hline Year & $2 \mathrm{D}$ or $3 \mathrm{D}$ & $\Delta x(\mathrm{~km})$ & \# & $\begin{array}{l}\text { References (superscripts indicate model configuration defined by the } \\
\text { footnotes) }\end{array}$ \\
\hline $1955-1959$ & $2 \mathrm{D}$ & - & 1 & Pearce (1955) \\
\hline 1960-1964 & $2 \mathrm{D}$ & $2-34$ & 3 & Fisher $(1961)^{1}$, Estoque $(1961,1962)^{1}$ \\
\hline 1965-1969 & $2 \mathrm{D}$ & $15-18$ & 2 & Magata $(1965)^{1}$, Moroz $(1967)^{1}$ \\
\hline \multirow[t]{2}{*}{ 1970-1974 } & $2 \mathrm{D}$ & $1-5$ & 4 & $\begin{array}{l}\text { Neumann and Mahrer }(1971,1974)^{5} \text {, Pearson }(1973)^{1}, \text { Lambert } \\
(1974)^{1}\end{array}$ \\
\hline & $3 \mathrm{D}$ & 11 & 3 & McPherson $(1970)^{1}$, Pielke $(1974 a, b)^{4}$ \\
\hline 1975-1979 & $2 \mathrm{D}$ & $2.5-8$ & 9 & $\begin{array}{l}\text { Neumann and Mahrer }(1975)^{5} \text {, Sheih and Moroz }(1975)^{1}, \text { Estoque } \\
\text { et al. }(1976)^{1} \text {, Mahrer and Pielke }(1976,1977)^{3}, \text { Physick } \\
(1976)^{4} \text {, Anthes }(1978)^{2} \text {, Asai and Mitsumoto }(1978)^{1} \\
\text { Ookouchi et al. }(1978)^{3}\end{array}$ \\
\hline \multirow[t]{2}{*}{ 1980-1984 } & $2 \mathrm{D}$ & $3-10$ & 8 & $\begin{array}{l}\text { Physick }(1980)^{4} \text {, Estoque and Gross }(1981)^{2} \text {, Alpert et al. }(1982)^{1} \text {, } \\
\text { Troen }(1982)^{1} \text {, Martin and Pielke }(1983)^{5} \text {, Pearson et al. }(1983)^{1} \text {, } \\
\text { Richiardone and Pearson }(1983)^{1}, \text { Clarke }(1984)^{2}\end{array}$ \\
\hline & $3 \mathrm{D}$ & $5-8$ & 2 & Kikuchi et al. $(1981)^{2}$, Segal et al. $(1983)^{3}$ \\
\hline \multirow[t]{2}{*}{ 1985-1989 } & $2 \mathrm{D}$ & $1-10$ & 14 & $\begin{array}{l}\text { Garratt and Physick }(1985)^{2} \text {, Mahrer and Segal }(1985)^{1} \text {, Physick } \\
\text { and Smith }(1985)^{3} \text {, Neumann and Savijarvi }(1986)^{1}, \text { Noonan and } \\
\text { Smith }(1986)^{2} \text {, Segal et al. }(1986)^{3} \text {, Arritt }(1987,1989)^{4} \text {, Briere } \\
(1987)^{1} \text {, Yan and Anthes }(1987,1988)^{2} \text {, Moon }(1988)^{8} \text {, Savijarvi } \\
\text { and Alestalo }(1988)^{1} \text {, Durand et al. }(1989)^{4}\end{array}$ \\
\hline & $3 \mathrm{D}$ & $8-22$ & 3 & Abbs $(1986)^{2}$, Song $(1986)^{4}$, Steyn and Mckendry $(1988)^{3}$ \\
\hline \multirow[t]{2}{*}{$1990-1994$} & $2 \mathrm{D}$ & $0.1-10$ & 14 & $\begin{array}{l}\text { Garratt et al. }(1990)^{4} \text {, Schlunzen }(1990)^{8} \text {, Bechtold et al. }(1991)^{2} \text {, } \\
\text { Nicholls et al. }(1991)^{8} \text {, Sha et al. }(1991,1993)^{1} \text {, Xian and Pielke } \\
(1991)^{8} \text {, Yang }(1991)^{1,5} \text {, Ado }(1992)^{1}, \text { Yoshikado }(1992)^{4} \text {, Arritt } \\
(1993)^{4} \text {, Feliks }(1993)^{1} \text {, Kuwagata et al. }(1994)^{2}, \text { Lu and Turco } \\
(1994)^{4}\end{array}$ \\
\hline & $3 \mathrm{D}$ & $2-8$ & 5 & $\begin{array}{l}\text { Zhong et al. }(1991)^{2} \text {, Boybeyi and Raman }(1992 a, b)^{8} \text {, Steyn and } \\
\text { Kallos }(1992)^{4}, \text { Zhong and Takle }(1993)^{2}\end{array}$ \\
\hline \multirow[t]{2}{*}{ 1995-1999 } & $2 \mathrm{D}$ & 3 & 9 & $\begin{array}{l}\text { Harris and Kotamarthi }(1995)^{8}, \text { Ramis and Romero }(1995)^{8} \text {, } \\
\text { Buckley and Kurzeja }(1997)^{8} \text {, Savijarvi }(1997)^{1}, \text { Finkele } \\
(1998)^{1} \text {, Shen }(1998)^{8} \text {, Tijm et al. }(1999 a, b)^{1}\end{array}$ \\
\hline & $3 \mathrm{D}$ & $0.1-10$ & 4 & $\begin{array}{l}\text { Franchito et al. }(1998)^{1} \text {, Grisogono et al. }(1998)^{1} \text {, Dailey and } \\
\text { Fovell }(1999)^{6} \text {, Rao et al. }(1999)^{8}\end{array}$ \\
\hline \multirow[t]{2}{*}{$2000-2004$} & $2 \mathrm{D}$ & $0.05-2$ & 4 & $\begin{array}{l}\text { Darby et al. (2002) }{ }^{8} \text {, Ogawa et al. (2003) }{ }^{1} \text {, Savijarvi and Matthews } \\
(2004)^{1} \text {, Sha et al. (2004) }\end{array}$ \\
\hline & $3 \mathrm{D}$ & $0.1-20$ & 18 & $\begin{array}{l}\text { Cai and Steyn }(2000)^{8} \text {, Clappier et al. }(2000)^{8} \text {, Kusaka et al. } \\
(2000)^{2} \text {, Rao and Fuelberg }(2000)^{8} \text {, Yimin and Lyons }(2000)^{8} \text {, } \\
\text { Baker et al. }(2001)^{8} \text {, Daggupaty }(2001)^{4} \text {, Fovell and Dailey } \\
(2001)^{6} \text {, Liu et al. }(2001)^{2} \text {, Samuelsson and Tjernstrom }(2001)^{3} \text {, } \\
\text { Ohashi and Kida }(2002,2004)^{2} \text {, Miao et al. }(2003)^{8} \text {, Stivari et al. } \\
(2003)^{8} \text {, Colby }(2004)^{8} \text {, Gilliam et al. }(2004)^{8} \text {, Zhu and Atkinson } \\
(2004)^{8} \text {, Marshall et al. }(2004)^{8}\end{array}$ \\
\hline \multirow[t]{2}{*}{$2005-2010$} & $2 \mathrm{D}$ & $0.3-3$ & 4 & Lemonsu et al. $(2006)^{8}$, Porson et al. $(2007 a, b, c)^{5}$ \\
\hline & $3 \mathrm{D}$ & $0.05-4$ & 14 & $\begin{array}{l}\text { Fovell }(2005)^{6} \text {, Zhang et al. }(2005)^{8} \text {, Novak and Colle }(2006)^{8} \text {, } \\
\text { Antonelli and Rotunno }(2007)^{5} \text {, Cunningham }(2007)^{5}, \text { Freitas } \\
\text { et al. }(2007)^{8} \text {, Srinivas et al. }(2007)^{8} \text {, Talbot et al. }(2007)^{8} \text {, } \\
\text { Thompson et al. }(2007)^{8} \text {, Cheng and Byun }(2008)^{8} \text {, Dandou et al. } \\
(2009)^{8} \text {, Levy et al. }(2009)^{8} \text {, Ries and Schlunzen }(2009)^{8} \text {, Kala } \\
\text { et al. }(2010)^{8}\end{array}$ \\
\hline
\end{tabular}


Table 1 continued

The approximate range of horizontal spatial scales $(\Delta x)$ and the total number (\#) of studies during each 5-yr period are provided

Model configurations. Type 1 Hydrostatic, dry, prescribed surface heat flux. Type 2 Hydrostatic, dry, with radiation and surface energy balance equation or force-restore method. Type 3 Hydrostatic, moist, prescribed surface heat flux. Type 4 Hydrostatic, moist, with radiation and surface energy balance equation, in some cases land surface and soil model. Type 5 Nonhydrostatic, dry, prescribed surface heat flux. Type 6 Nonhydrostatic, dry, with radiation and surface energy balance equation. Type 7 Nonhydrostatic, moist, prescribed surface heat flux. Type 8 Nonhydrsotatic, moist (occasionally dry), variations of full physics (radiation, cumulus, land surface model soil layers) and PBL schemes

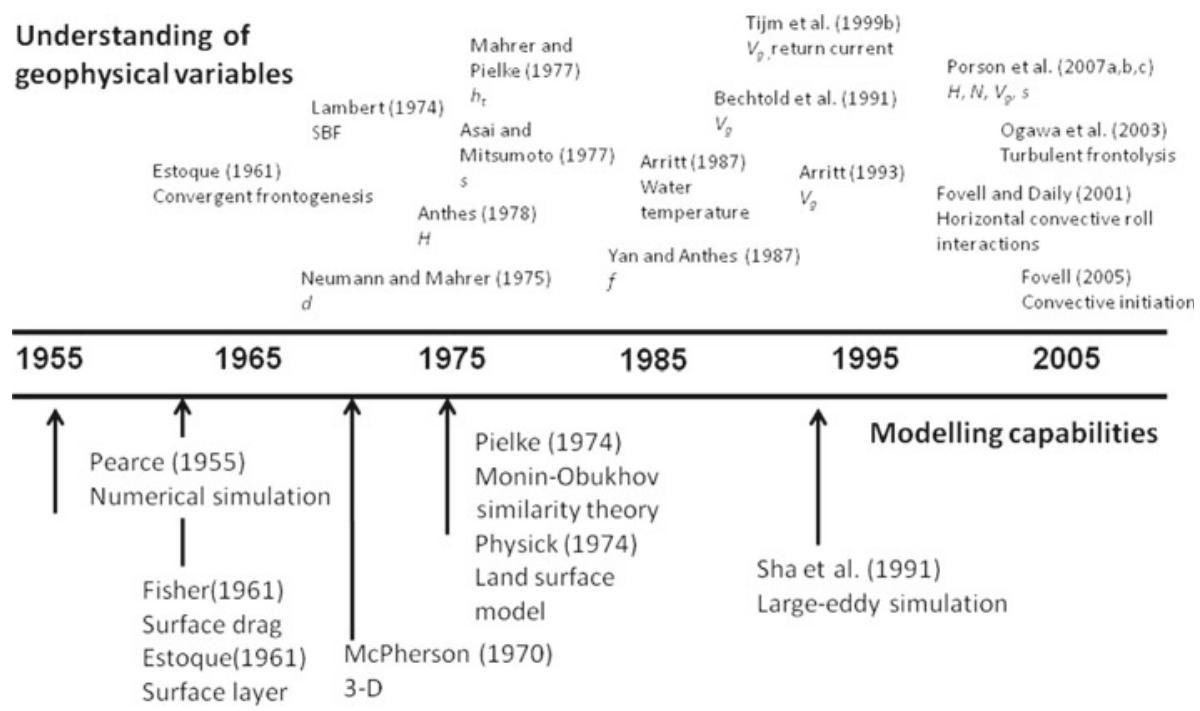

Fig. 3 Time line of major advancements in understanding in terms of the geophysical variables defined in Fig. 1 (top) and modelling capabilities (bottom) of SB

transport of heat, moisture, and momentum. Through the 1970s, turbulence in the surface layer was generally treated using simple K-theory, assuming constant fluxes, and with empirical formulations for turbulent transport in the overlying transition layer. From around 1980 to the present day, Monin-Obukov similarity theory has been used most commonly to derive surface-layer fluxes, with prognostic turbulent kinetic energy formulations typically used for transition layer turbulence.

Beginning with the first numerical simulation by Pearce (1955), there has been a steady increase in the number of scientific investigations devoted to sea breezes. Of the studies listed in Table 1, over twice as many were devoted to sea breezes between 1985 and 2004 than between 1965 and 1984. Most early numerical studies of sea breezes were idealized simulations, while recent studies primarily specify initial and lateral boundary conditions from observations.

Key advancements in numerical modelling are summarized further in Fig. 3. Through the 1970s most studies used two-dimensional hydrostatic models with horizontal grid spacing every $2-15 \mathrm{~km}$ (Table 1). Decreased horizontal grid spacing in two-dimensional simulations took place during the 1980s while three-dimensional models continued to be used rather sparingly. Two-dimensional non-hydrostatic models began to be used more frequently in the 
1990s, with a notable increase in three-dimensional simulations beginning around 2000. In the past 20 years a slow increase in the number of studies with sufficient horizontal resolution $(\approx 1 \mathrm{~km})$ to model the sea-breeze front in detail has occurred. Some landmark (mostly idealized) numerical studies that improved understanding of the effects of geophysical variables on sea breezes are summarized in Fig. 3.

\subsection{Temporally-dependent Geophysical Variables}

\subsubsection{Land-Surface Sensible Heat Flux $(H)$}

Differential sensible heating during the daytime between land and water surfaces result in the horizontal gradients in temperature $(\Delta T)$ that drive sea breezes (Steyn 2003; Kruit et al. 2004). There is general agreement that the horizontal temperature gradient between the water and land surface beyond the sea breeze is needed (Kruit et al. 2004), although several scaling studies yielded superior results using horizontal temperature gradients adjacent to the shoreline (Porson et al. 2007a; Kala et al. 2010). In any case, $\Delta T$ is generally computed using observations near the coast, simply as a result of available data resources (Steyn 2003).

The dependence of sea breezes on the magnitude of the land-surface sensible heat flux $(H)$ and the period $(\omega)$ over which the diurnal heating takes place can be seen in the scaling relations in Table 2 for $u$ and $h$ due to Steyn (1998) and Porson et al. (2007a). Despite this dependence, there is no consistent approach in the literature to describe time-integrated differential sensible heating, since most numerical studies of sea breezes have focused on dynamical, rather than thermodynamical, aspects of these systems (Kuwagata et al. 1994). The land-surface sensible heat flux in numerical simulations is either directly prescribed through a time-varying sinusoidal function (set to near zero over the water surface) or indirectly specified through changes in vegetation type, soil moisture content, or latitude. Since nearly all studies focus on summer months in the mid-latitudes, with generally a 12-h period of diurnal heating, the maximum land-surface sensible heat flux used in each study provides a basis for comparison and is used hereafter.

Table 2 Scaling relations for sea-breeze vertical $(h)$ and horizontal $(l)$ length scales and horizontal velocity scale $(u)$. Variables listed are land surface sensible heat flux $\left(H, \mathrm{~K} \mathrm{~m} \mathrm{~s}^{-1}\right)$, Brunt-Vaisala frequency $\left(N, \mathrm{~s}^{-1}\right)$, vertical acceleration $\left(g, \mathrm{~m} \mathrm{~s}^{-2}\right)$, air density $\left(\rho, \mathrm{kg} \mathrm{m}^{-3}\right)$, temperature difference between boundary layer air over water and land $(\Delta T, \mathrm{~K})$, reference temperature of the boundary layer $(T, \mathrm{~K})$, Coriolis parametre $\left(f, \mathrm{~s}^{-1}\right)$, period of diurnal heating $(\omega, \mathrm{s})$, water body dimension $(d, \mathrm{~m})$, and time since model integration start $(t, \mathrm{~s})$. Segal et al. (1997) based on theoretical analysis, Steyn (1998) based on observations, Porson et al. (2007a) and Antonelli and Rotunno (2007) based on numerical simulations

\begin{tabular}{lllll}
\hline & Segal et al. $(1997)^{\mathrm{a}}$ & Steyn (1998) & Porson et al. (2007a) & Antonelli and Rotunno (2007) \\
\hline$h$ & $h=\sqrt{\frac{2.4 \int_{t 1}^{t 2} H d t}{\rho C_{p} \frac{\Delta \theta}{\Delta Z}}}$ & $h=\frac{H}{\omega \Delta T}$ & $h=\left(\frac{N}{\omega}\right)^{1 / 6} \sqrt{\frac{g H}{T \omega}} \frac{1}{N}$ & $h=\frac{\sqrt{H t}}{N}$ \\
$u$ & $u=\sqrt[3]{1.2 \frac{g H d}{\rho C_{p} T\left(1+\frac{d}{l}\right)^{2}}}$ & $u=\frac{g \Delta T}{T} \frac{1}{N}$ & $u=.33 \sqrt{\frac{g H}{T \omega}}$ & $u=.32 \frac{\sqrt{H t}(N t)^{0.1}}{\sqrt{1+\left(.37 \frac{f}{N} N t\right)^{2}}}$ \\
$l$ & $l \propto \sqrt{H}$ & $l=\frac{N H}{\omega^{2} \Delta T}$ & & $l \approx u t$ \\
\hline
\end{tabular}

${ }^{\text {a }}$ Units for $H$ are $\mathrm{W} \mathrm{m}^{-2}$ for Segal et al. (1997) 
Table 3 summarizes the key findings from studies that have examined the role of differential sensible heating. As the fundamental driver of sea breezes, the magnitude of the land-surface sensible heat flux influences all aspects of the circulation. The scaling analyses summarized in Table 2 help to quantify the impacts of the land-surface sensible heat flux on sea-breeze characteristics based on selected observational (Steyn 1998), theoretical (Segal et al. 1997), and numerical (Porson et al. 2007a; Antonelli and Rotunno 2007) scaling studies. Segal et al. (1997), Porson et al. (2007a), Antonelli and Rotunno (2007), and Kala et al. (2010) agree that the depth $(h)$ of the sea breeze is proportional to $\sqrt{H}$, while the horizontal velocity scale $(u)$ is proportional to either $\sqrt{H}$ or the cube root of $H$ (Segal et al. 1997). Troen (1982), Steyn (1998), Shen (1998), and Miao et al. (2003) found that $h$ varied somewhat more strongly with $H$, but which may be due to additional effects, such as a small water body dimension (Shen 1998), local complex terrain (Miao et al. 2003), or with $h$ defined inland from the shoreline (Troen 1982).

Comparatively few studies have investigated the relationship between the land-surface sensible heat flux and the maximum inland penetration $(l)$ and inland penetration speed of the sea-breeze front. Figure 4 summarizes the results of several numerical studies of $l$ as a function of the time of day and the land-surface sensible heat flux. In these studies, high

Table 3 Summary of key results from numerical studies pertaining to land-surface sensible heat flux $(H)$

\begin{tabular}{|c|c|c|}
\hline Study focus & Findings & References \\
\hline $\begin{array}{l}\text { Magnitude of time-integrated } \\
\text { land-surface sensible heat flux } \\
\text { (prescribed } H \text {, land use, soil } \\
\text { moisture) }\end{array}$ & $\begin{array}{l}\text { Magnitude of } u, w, l, h \text { increase } \\
\text { with increasing } H \\
\text { Scaling studies suggest } u, h \text { pro- } \\
\text { portional to } \sqrt{H} \\
\text { Dependence of } l \text { to changes in } H \\
\text { unclear } \\
\text { Convective turbulence leads to } \\
\text { frontolysis of SBF and after- } \\
\text { noon slowing of inland penetra- } \\
\text { tion speed } \\
w \text { may be most sensitive to } \\
\text { variations in } H\end{array}$ & $\begin{array}{l}\text { Anthes (1978), Physick (1980), } \\
\text { Troen (1982), Ookouchi et al. } \\
\text { (1984), Segal et al. (1988, } \\
\text { 1997), Yan and Anthes (1988), } \\
\text { Sha et al. (1991), Shen (1998), } \\
\text { Tijm et al. (1999b), Miao et al. } \\
\text { (2003), Marshall et al. (2004), } \\
\text { Antonelli and Rotunno (2007) } \\
\text { Porson et al. (2007a), Kala } \\
\text { et al. (2010) }\end{array}$ \\
\hline Area of heated surface & $\begin{array}{l}\text { Magnitude of } l, h, u, w \text { increase } \\
\text { with increasing scale of heated } \\
\text { surface (up to order } 50-100 \mathrm{~km} \text { ) } \\
\text { Constructive and destructive } \\
\text { interactions between SB and } \\
\text { urban circulations. Distance to } \\
\text { ocean and size of urban area } \\
\text { important }\end{array}$ & $\begin{array}{l}\text { Neumann and Mahrer (1974), } \\
\text { Mahrer and Segal (1985), Yan } \\
\text { and Anthes (1988), Yoshikado } \\
\text { (1990, 1992), Xian and Pielke } \\
\text { (1991), Yang (1991), Ado } \\
\text { (1992), Kusaka et al. (2000), } \\
\text { Ohashi and Kida (2002, 2004), } \\
\text { Savijarvi and Matthews (2004), } \\
\text { Lemonsu et al. (2006), } \\
\text { Courault et al. (2007), Freitas } \\
\text { et al. (2007), Thompson et al. } \\
\text { (2007), Cheng and Byun } \\
\text { (2008), Dandou et al. (2009) }\end{array}$ \\
\hline Shoreline gradients in $H$ & $l$ reduced due to gradients in $H$ & Schlunzen (1990) \\
\hline Water temperature & $\begin{array}{l}\text { SB relatively insensitive to } \\
\text { changes in water temperature } \\
\text { unless water temperature is } \\
\text { high enough to induce } \\
\text { boundary-layer convection or } \\
\text { moderate } V_{g} \text { exists }\end{array}$ & $\begin{array}{l}\text { Segal and Pielke (1985), Arritt } \\
\quad(1987,1989)\end{array}$ \\
\hline
\end{tabular}


Fig. 4 Inland penetration distance $l$ of SBF as a function of local solar time (LST). Dot-dash lines represent findings of Physick (1980) using high $H$ (240 $\mathrm{W} \mathrm{m}^{-2}$ upper line) and low $H\left(84 \mathrm{~W} \mathrm{~m}^{-2}\right.$ lower line $)$. Dotted lines represent findings of Tijm et al. (1999b) using high $H$ (250 $\mathrm{W} \mathrm{m}^{-2}$ upper line) and low $H\left(150 \mathrm{~W} \mathrm{~m}^{-2}\right.$ lower line $)$. Solid black line represents findings of Ogawa et al. (2003). Hypothetical high $H$ (upper + symbols) and low $H$ (lower + symbols) from Antonelli and Rotunno (2007) scaling relations defined in Table 3. All studies have $V_{g}=0$, except Tijm et al. (1999b), where $V_{g}=2 \mathrm{~ms}^{-1}$ offshore

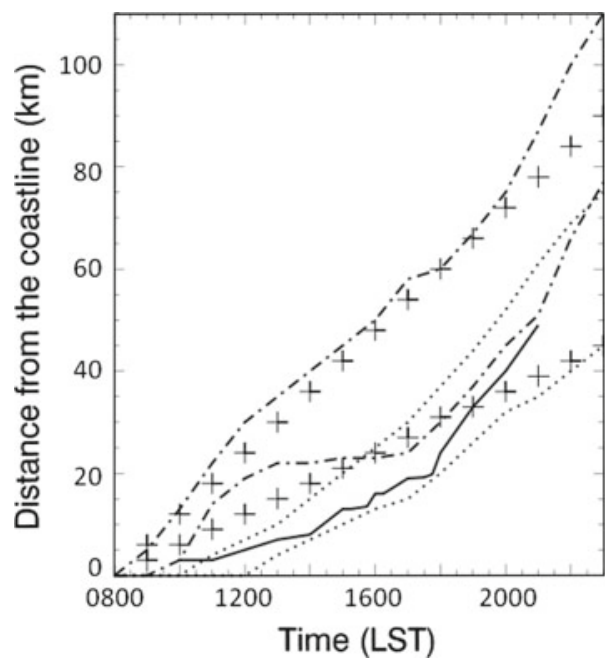

values of the land-surface sensible heat flux lead to greater inland penetration and higher penetration speeds. Although Segal et al. (1997) also show a relatively strong variation of $l$ with the land-surface sensible heat flux, Miao et al. (2003) and Troen (1982) suggest less dependence. This ambiguity may arise from two opposing tendencies. Increasing the landsurface sensible heat flux tends to increase the overall intensity of sea breezes, which acts to increase $l$. However, as the land-surface sensible heat flux increases, turbulent convection also increases, which acts to destroy the thermal gradient along the sea-breeze front. This process, known as turbulent frontolysis, decreases the inland penetration of the sea-breeze front through a weakening of the horizontal temperature gradient during peak daytime heating and increasing drag (Simpson et al. 1977; Abbs and Physick 1992; Ogawa et al. 2003).

Turbulence in the convective boundary layer has a noted effect on frontal dynamics (Wood et al. 1999; Stephan et al. 1999; Ogawa et al. 2003). The inland penetration speed of sea breezes typically decreases during early afternoon due to the aforementioned turbulent frontolysis, before accelerating again during the late afternoon and evening when turbulence diminishes. As shown in Fig. 4, there is a pronounced decrease in the inland penetration speed between 1400 and 1800 local solar time (LST) with an inland acceleration after 1800 LST for low, but not high, values of the land-surface sensible heat flux according to Physick (1980) and Tijm et al. (1999b). Several authors have discussed the inability of some numerical studies to reproduce the afternoon deceleration of the sea-breeze front, presumably due to poor turbulence resolution. The numerical model of Ogawa et al. (2003) was operated with fine enough grid spacing to simulate several periodic variations (surges) in the afternoon inland penetration speed associated with turbulence-generated frontogenesis and frontolysis between 1400 and 1800 LST (Fig. 4).

The dependence of vertical motion associated with the sea-breeze front on the land-surface sensible heat flux has been largely neglected, in part due to the inability of hydrostatic models with horizontal grid spacing greater than $1 \mathrm{~km}$ to accurately simulate this component of sea breezes. Indications are that the vertical velocity $w$ may be highly sensitive to variations in the land-surface sensible heat flux (Troen 1982; Yang 1991; Shen 1998; Miao et al. 2003). The effects of variations in the land-surface sensible heat flux on offshore compensatory subsidence associated with sea breezes have not been thoroughly investigated, although Shen 
(1998) found that vertical motions in the subsidence zone over a small lake were relatively insensitive to variations in the land-surface sensible heat flux.

Several other aspects of the dependence of sea breezes on the land-surface sensible heat flux have been investigated, including the size of the heated land surface (Xian and Pielke 1991; Savijarvi and Matthews 2004). Neumann and Mahrer (1974), Mahrer and Segal (1985), and Yan and Anthes (1988) found that as the spatial extent of heating increases (up to $\approx 50$ $100 \mathrm{~km}$ ), sea breezes tend to become stronger and deeper (i.e., small islands or strips of land have weaker sea breezes than their larger counterparts). However, Yang (1991) found that sea breezes were less developed for increasingly larger heating scales. Schlunzen (1990) concluded that horizontal gradients in the land-surface sensible heat flux affect $l$ more than $u$ and $w$.

Sea-breeze characteristics may also be weakened or strengthened by interactions (e.g., frictional retardation, thermal coupling) with an urban heat island circulation. The size of the urban area, distance between the urban area and the coast, and surrounding topography modulate these highly variable (in both sign and magnitude) interactions (Yoshikado 1990, 1992; Ado 1992; Kusaka et al. 2000; Ohashi and Kida 2002, 2004; Lemonsu et al. 2006; Freitas et al. 2007; Thompson et al. 2007; Cheng and Byun 2008; Dandou et al. 2009).

Although most studies specify constant values of water surface temperature, variations in water temperature have been shown to influence both sea and lake breezes (Segal and Pielke 1985; Arritt 1987; Franchito et al. 1998, 2008). Segal and Pielke (1985) found that lake temperature had a small effect on the lake breeze except in the case that included a moderate geostrophic wind. Arritt (1987) found negligible effects on the lake breeze as well until lake temperature was increased sufficiently to generate convective instability over the lake, in which case the lake breeze was significantly weakened. Porson et al. (2007b) noted the possible effects of diurnal variations in water surface temperatures over shallow lakes. Lakes in deep valleys may be more sensitive to lake temperature variations due to interactions between boundary-layer stability and topography (Segal et al. 1983).

\subsubsection{Ambient Geostrophic Wind $\left(V_{g}\right)$}

The dependence of the local sea-breeze circulation on the synoptic-scale background geostrophic flow (referred to hereafter as the geostrophic wind, $V_{g}$ ) has been and continues to be extensively studied (Gilliam et al. 2004; Porson et al. 2007c; Molina and Chen 2009). Drobinski et al. (2006) found that sea-breeze scaling laws due to Steyn $(1998,2003)$ and others that ignore the geostrophic wind fail to predict observed sea-breeze characteristics. The geostrophic wind is typically divided into shore-perpendicular (onshore/offshore) and shore-parallel components, with the shore-perpendicular winds being of primary interest, since the effect of a shore-parallel flow on sea breezes is generally small (Savijarvi and Alestalo 1988). The onshore (offshore) shore-perpendicular geostrophic flow combines with (opposes) the low-level sea-breeze feeder flow.

The magnitude of the horizontal temperature gradient associated with the sea-breeze front and the sharpness of this gradient can be significantly enhanced (weakened) by offshore (onshore) geostrophic winds. The kinematic frontogenesis equation formulated by Miller (1948), and summarized by Miller et al. (2003) in a two-dimensional $x, z$ coordinate system is

$$
\frac{d \theta_{x}}{d t}=-\frac{\partial u}{\partial x} \theta_{x}-\frac{\partial w}{\partial x} \theta_{z}+K \nabla^{2} \theta_{x}
$$


where the three terms on the right-hand side of (1) represent the contributions of convergence, tilting, and turbulence, respectively, to the total tendency of the horizontal potential temperature gradient $\left(\theta_{x}\right)$ associated with the sea-breeze front. An offshore (onshore) geostrophic wind leads to frontogenesis (frontolysis). Tilting of the vertical temperature gradient into the horizontal plane of the sea-breeze front can also be an important source of frontogenesis (Arritt 1993; Ogawa et al. 2003). While turbulence in the atmosphere over land initially acts to strengthen the horizontal temperature gradient at a coastline, turbulent mixing effects are frontolytical once a well-developed sea-breeze front is formed.

Table 4 summarizes the effects of offshore and onshore geostrophic flow on sea breezes. Most numerical studies with a non-zero background flow have focused on the impact of offshore geostrophic flow. If the offshore geostrophic wind speed is above some critical value, then sea breezes do not form as the synoptic pressure gradient effectively cancels the local pressure gradient. The critical value of the offshore geostrophic wind above which sea breezes are likely to be absent has been found to be $6-11 \mathrm{~m} \mathrm{~s}^{-1}$, depending on the strength of the land-water temperature gradient (Biggs and Graves 1962; Arritt 1993; Porson et al. 2007c). For small and medium-sized lakes, the critical value is unknown, but likely ranges between $3-5 \mathrm{~m} \mathrm{~s}^{-1}$ (Segal et al. 1997). For offshore winds greater than $4-8 \mathrm{~m} \mathrm{~s}^{-1}$ but less than

Table 4 Summary of key results from numerical studies pertaining to ambient geostrophic wind $\left(V_{g}\right)$

\begin{tabular}{|c|c|c|}
\hline Study focus & Findings & References \\
\hline $\begin{array}{l}\text { Offshore (OFF) ambient } \\
\text { geostrophic wind }\end{array}$ & $\begin{array}{l}\text { OFF } V_{g}>6-11 \mathrm{~ms}^{-1} \text { no } \mathrm{SB} \text { form } \\
\text { (smaller } V_{g} \text { for lakes) } \\
\text { OFF } V_{g}>4-8 \mathrm{~m} \mathrm{~s}^{-1} \text { but }<6-10 \mathrm{~m} \mathrm{~s}^{-1} \\
\text { SBF stalls at coastline } \\
\text { OFF } V_{g} \text { shifts SB seaward } \\
\text { SB may lose closed circulation char- } \\
\text { acteristics (no return flow) } \\
l \text { decreases with increasing OFF } V_{g} \\
\text { OFF } V_{g} \text { delays inland movement of } \\
\text { SBF } \\
\text { Magnitude of } u, w \text { as perturbations } \\
\text { from the mean flow generally in- } \\
\text { crease (decrease) with increasing } \\
\text { OFF } V_{g} \text { for } V_{g} \text { less (greater) than } \\
\text { 4-6ms }-1 \\
\text { Relationship between OFF } V_{g} \text { and } h \\
\text { unclear, although in many cases } \\
\text { increases in OFF } V_{g} \text { result in } \\
\text { decreases in } h\end{array}$ & $\begin{array}{l}\text { Estoque (1962), Physick (1976, } \\
\text { 1980), Troen (1982), Pearson et al. } \\
\text { (1983), Savijarvi and Alestalo } \\
\text { (1988), Arritt (1989, 1993), } \\
\text { Bechtold et al. (1991), Yang } \\
\text { (1991), Zhong and Takle (1993), } \\
\text { Savijarvi (1997), Finkele (1998), } \\
\text { Tijm et al. (1999b), Gilliam et al. } \\
\text { (2004), Porson et al. (2007c) }\end{array}$ \\
\hline $\begin{array}{l}\text { Onshore }(\mathrm{ON}) \text { ambient } \\
\text { geostrophic wind }\end{array}$ & $\begin{array}{l}\text { ON } V_{g}>3-5 \mathrm{~ms}^{-1} \text { no SB form (or } \\
\text { indistinguishable) } \\
\text { ON } V_{g} \text { shifts SB landward } \\
\text { Magnitude of } u, w \text { as perturbations } \\
\text { from the mean flow decrease with } \\
\text { increasing ON } V_{g} \\
\text { Magnitude of } h \text { generally decreases } \\
\text { with increasing ON } V_{g}\end{array}$ & $\begin{array}{l}\text { Estoque (1962), Estoque and Gross } \\
\text { (1981), Troen (1982), Pearson et al. } \\
\text { (1983), Clarke (1984), Savijarvi } \\
\text { and Alestalo (1988), Arritt (1989, } \\
\text { 1993), Zhong and Takle (1993), } \\
\text { Gilliam et al. (2004) }\end{array}$ \\
\hline Other & $\begin{array}{l}\text { Peninsula or water body dimensions, } \\
\text { atmospheric stability and vertical } \\
\text { wind shear modify sea-breeze } \\
\text { response to } V_{g}\end{array}$ & $\begin{array}{l}\text { Xian and Pielke (1991), Boybeyi and } \\
\text { Raman (1992a,b), Chen and Oke } \\
\text { (1994) }\end{array}$ \\
\hline
\end{tabular}

$\mathrm{SB}=$ sea breeze; $\mathrm{SBF}=$ sea-breeze front 
$6-10 \mathrm{~m} \mathrm{~s}^{-1}$, the sea-breeze front may stall at the coastline where shear instabilities help to retard its inland penetration (Grisogono et al. 1998). Offshore geostrophic flow also shifts sea breezes so that they are no longer symmetric about the shoreline (Finkele et al. 1995) and may then not be closed circulations (Banta et al. 1993). For offshore geostrophic flows of $1-2 \mathrm{~m} \mathrm{~s}^{-1}, l$ is on the order of $50 \mathrm{~km}$, while $l$ is on the order of $10 \mathrm{~km}$ for offshore geostrophic flows of 4-5 $\mathrm{m} \mathrm{s}^{-1}$ and onshore penetration occurs later in the afternoon (Arritt 1993; Tijm et al. 1999b; Porson et al. 2007c). Inland penetration speed of the sea-breeze front is likewise decreased by increasing offshore geostrophic flow, with acceleration of the inland penetration noted in the late afternoon (see Fig. 4 for an example of delayed inland penetration with a $2 \mathrm{~m} \mathrm{~s}^{-1}$ offshore geostrophic flow).

Divergent frontolysis associated with onshore geostrophic flow rapidly weakens the seabreeze circulation (Arritt 1993); an onshore geostrophic wind of only $2-4 \mathrm{~m} \mathrm{~s}^{-1}$ is sufficient to make sea breezes indistinguishable from the background flow (Savijarvi and Alestalo 1988; Arritt 1993). However, several cases with moderate onshore flow have been associated with strong sea-breeze surges over $100 \mathrm{~km}$ inland from the coast in Australia (Clarke 1984; Garratt and Physick 1985). Because of a general lack of observational data over coastal waters, less attention has been given to the offshore horizontal extent of sea breezes. It is also more difficult to distinguish where the circulation terminates over the water due a lack of a thermal boundary in that region (Arritt 1989). Finkele (1998) found that the horizontal extension of the circulation over the water was less sensitive to the offshore geostrophic flow than $l$, while Arritt (1989) found that onshore geostrophic flow greatly suppressed the offshore extent of sea breezes by shifting the entire circulation cell landward.

Most studies agree that $w$ and $u$ in the vicinity of the sea-breeze front are modified for an offshore ambient geostrophic wind due to convergent frontogenesis (note that $u$ in these cases refers to the "perturbation" $u$, which is subtracted from the mean background flow). Increasing offshore geostrophic flow from 0 to $4-6 \mathrm{~m} \mathrm{~s}^{-1}$ increases $u$ and $w$, with a higher offshore ambient geostrophic wind (greater than $4-6 \mathrm{~m} \mathrm{~s}^{-1}$ ) resulting in a slight weakening of the circulation. The highest $w$ and $u$ for sea breezes associated with offshore geostrophic winds have been found to occur when frontogenesis is maximized and the inland movement of the sea-breeze front is stalled by the offshore geostrophic wind (Savijarvi and Alestalo 1988; Bechtold et al. 1991; Arritt 1993). Onshore geostrophic winds of any speed or offshore geostrophic flow greater than 5-7 $\mathrm{m} \mathrm{s}^{-1}$ results in rapid weakening of $u$ and $w$ (Troen 1982; Arritt 1989, 1993; Bechtold et al. 1991; Xian and Pielke 1991; Yang 1991).

Sufficiently strong geostrophic winds $\left(>4 \mathrm{~m} \mathrm{~s}^{-1}\right)$ act to decrease $h$ through mechanical turbulence along the upper boundary of the low-level flow. There is no agreement in the literature on the effect of offshore geostrophic winds less than around $4 \mathrm{~m} \mathrm{~s}^{-1}$ on $h$ since the mechanical turbulence is offset to varying degrees by frontogenesis that may locally strengthen and deepen the circulation. Arritt (1993) and Zhong and Takle (1993) found that the vertical extent of sea breezes, particularly in the region of the sea-breeze head, decreases with increasing offshore geostrophic winds while Estoque (1962) and Troen (1982) found little change in $h$ with increasing geostrophic flow.

Vertical wind shear of the geostrophic wind may also modify sea breezes. Pearson et al. (1983) indicate that $u$ and the rate of inland movement of the sea-breeze front are unaffected by vertical wind shear. However, Boybeyi and Raman (1992a) suggest that a constant vertical wind shear of $2 \mathrm{~m} \mathrm{~s}^{-1} \mathrm{~km}^{-1}$ increases vertical velocities and convergence near the sea-breeze front, while Chen and Oke (1994) found mechanical mixing of the low-level sea-breeze flow results from vertical wind shear. 
Table 5 Summary of key results from numerical studies pertaining to atmospheric stability $(N)$

\begin{tabular}{|c|c|c|}
\hline Study focus & Findings & References \\
\hline $\begin{array}{l}\text { Initial atmospheric } \\
\text { stability }\end{array}$ & $\begin{array}{l}\text { Most studies agree with linear theory } \\
\text { Magnitude of } u, l \text { decrease slightly with } \\
\text { increasing } N \\
\text { Magnitude of } w \text { and } h \text { decrease more } \\
\text { rapidly with increasing } N\end{array}$ & $\begin{array}{l}\text { Troen (1982), Arritt (1989, 1993), } \\
\text { Bechtold et al. (1991), Yang (1991), } \\
\text { Wang et al. (1998), Tijm et al. (1999b), } \\
\text { Antonelli and Rotunno (2007), Porson } \\
\text { et al. (2007b) }\end{array}$ \\
\hline Interactions & $\begin{array}{l}\text { For high (low) } N \text {, circulation less (more) } \\
\text { sensitive to area of surface heating and } \\
\text { geostrophic wind } \\
\text { Initial inversion strength, initial } \\
\text { boundary-layer depth, terrain slope, } \\
\text { and multiple inversions also factors }\end{array}$ & $\begin{array}{l}\text { Feliks (1993), Xian and Pielke (1991), } \\
\text { Tijm et al. (1999a), Talbot et al. (2007) }\end{array}$ \\
\hline
\end{tabular}

\subsubsection{Atmospheric Stability $(N)$ and Moisture $(q)$}

The effects of atmospheric stability $(N)$ on sea breezes have been examined primarily through observational scaling and linear theory. The numerical scaling analyses of Porson et al. (2007a) and Antonelli and Rotunno (2007) found an inverse relationship between $h$ and stability (Table 2). Many numerical studies, however, only qualitatively discuss their results for the sea-breeze length scales $h$ and $l$ in terms of Rotunno (1983) linear theory:

$$
l=\frac{N h}{\sqrt{\omega^{2}-f^{2}}}
$$

for a latitude $<30^{\circ}$,

$$
l=\frac{N h}{\sqrt{f^{2}-\omega^{2}}}
$$

for a latitude $\geq 30^{\circ}$,

where $\omega$ represents the diurnal cycle of heating and cooling, $f$ is the Coriolis parameter, and stability is expressed in terms of the Brunt-Vaisala frequency. However, not surprisingly, contradictions exist between linear theory and some numerical results.

As shown in Table 5, most numerical studies and scaling analyses agree that: (1) a weakly stably-stratified atmosphere provides a more favorable environment for sea breezes than does a strongly stably-stratified environment, which acts to "damp" the circulation, and (2) variations in stability affect $h$ and $w$ more strongly than $l$ and $u$ (Atkinson 1981). Mak and Walsh (1976) show that diurnal differences in stability are the fundamental reason why nighttime land breezes are weaker than daytime sea breezes.

The atmospheric stability specified in approximately $75 \%$ of the numerical simulations reviewed in our study cluster around that of a standard atmosphere $\left(4.0-7.0 \mathrm{~K} \mathrm{~km}^{-1}\right)$. Only a few studies have investigated the characteristics of sea breezes when the initial temperature profile deviates substantively from the standard atmosphere (Garratt and Physick 1985; Yan and Anthes 1987; Savijarvi and Alestalo 1988). Increasing stability has been found to decrease $h$ (Troen 1982; Arritt 1989, 1993; Xian and Pielke 1991; Porson et al. 2007a), while a similar dependence has been found between stability and $w$ (Bechtold et al. 1991; Yang 1991; Arritt 1993; Wang et al. 1998). Complex interactions between stability and geostrophic winds, terrain height, and terrain slope are recognized to be important too; for example, Xian 
and Pielke (1991) found that for high stability, $u$ becomes insensitive to the size of a heated peninsula, while several authors have noted that decreasing stability increases the dependence of sea breezes on the geostrophic flow.

According to linear theory (Walsh 1974; Rotunno 1983), $u$ is inversely proportional to stability while $l$ is proportional to stability, i.e., increasing stability leads to slightly weaker winds near the shoreline and increased inland extent. In agreement with linear theory, Yang (1991) found $u$ to decrease slightly with increasing stability. However, there remains disagreement between studies on the dependence of $l$ on stability. Arritt (1989) found that increasing stability leads to slight increases in the offshore extent of sea breezes, while Troen (1982) and Xian and Pielke (1991) found that $l$ decreases slightly with increasing stability.

The impact of elevated stable layers, multiple stable layers, or near-surface inversions has also not been systematically analyzed. Tijm et al. (1999a) found that the strength of the seabreeze return current and the so-called "return-return current" (caused by overcompensation of mass by the return current) were a function of the initial boundary-layer depth and stability. Feliks (1993) found that a sea-breeze circulation lowered the coastal marine inversion due to the subsidence during the day and raised the inversion at night due to the advection of marine air.

Atmospheric moisture $(q)$ influences sea breezes in a variety of ways, none of which has been thoroughly explored. Moistening of the shallow sea-breeze flow can occur rapidly through the surface evaporation of soil moisture (Baker et al. 2001), and the available low-level moisture in turn modulates the frequency of moist convection along the sea-breeze front. Convergence between the sea-breeze front and a wide range of other features leads to convective initiation (Nicholls et al. 1991; Boybeyi and Raman 1992b; Shepherd et al. 2001; Fovell 2005). The effect of the convection itself on the characteristics of sea breezes has been explored by Song (1986) and Moon (1988); Moon (1988) found that convective feedbacks strengthened $u, w$, and $h$, while Song (1986) found that deep convection stretches sea breezes vertically. Ambient cloud cover weakens sea breezes due to the loss of incoming solar radiation (Segal et al. 1986).

\subsection{Location-dependent Geophysical Variables}

\subsubsection{Water Body Dimensions (d) and Shoreline Curvature ( $r$ )}

Although for sea breezes the water body dimensions can be assumed infinite, variations in water body dimensions $(d)$ on lake breezes are increasingly important due to the anthropogenic drying of lake systems such as Lake Chad, the Dead Sea, and the Aral Sea (Small et al. 2001). Many numerical studies use a circular or slab-symmetric lake such that a single dimension perpendicular to the shoreline of interest is sufficient (Fig. 1). Segal et al. (1997) were the only investigators to systematically vary lake size; no study has ever systematically varied water body dimensions in a three-dimensional setting with different water body dimensions along both axes of a water body. Differences in model set-up and curvature effects for circular lakes make comparisons difficult between the studies. Water body dimensions are also an important factor for sea breezes associated with semi-enclosed bays, which have the added complication of interactions between the bay breeze and the large-scale sea breeze (Abbs 1986).

Lake breezes associated with large lakes $(d>100 \mathrm{~km})$ have virtually indistinguishable characteristics from sea breezes with infinite dimensions (Table 6). However, this assumption may not be true in all circumstances, since Zhu and Atkinson (2004) found that the wider 
southern Persian Gulf $(\approx 400 \mathrm{~km})$ experienced stronger gulf breezes than the northern areas $(\approx 250 \mathrm{~km})$.

For medium $(d \approx 50-100 \mathrm{~km})$ and small $(d \approx 5-50 \mathrm{~km})$ water bodies, the characteristics and intensity of sea breezes vary non-linearly due in part to shoreline curvature effects (Boybeyi and Raman 1992a). The overlying boundary layer over a small lake or gulf is subject to greater influence from the ambient land boundary layer in addition to the two mirror circulations competing for limited cool, low-level air. As the size of a water body decreases, the associated circulations become less well-developed, i.e., smaller $u$ and $w$, shallower $h$, with less inland penetration and weaker fronts (Table 6). The relative increases in $u$ and $w$ for increases in lake dimensions between 5 and $50 \mathrm{~km}$ are significantly larger than the increases associated with further increases in water body dimensions between 50 and 100 km (Neumann and Mahrer 1975; Physick 1976; Boybeyi and Raman 1992a; Segal et al. 1997). In contrast, offshore subsidence may increase with decreasing water body dimensions due to enhanced convergence between the two mirror circulations (Physick 1976; Sun et al. 1997). Little is known about the dependence of $h$ and $l$ on the magnitude of the water body dimensions except that smaller water body dimensions tend to lead to smaller $h$ and $l$ (Physick 1976; Zhong et al. 1991).

The frequency of occurrence of sea breezes diminishes as water body dimensions decrease, as smaller-scale circulations are more easily destroyed by the prevailing background geostrophic flow. While the magnitude of the geostrophic wind needed to destroy sea breezes for given water body dimensions has not been studied in detail, Shen (1998) found that a lake breeze failed to form for a $5 \mathrm{~km}$ lake with a geostrophic wind of $4 \mathrm{~m} \mathrm{~s}^{-1}$.

Spatial heterogeneities in the land-surface sensible heat flux associated with islands or strips of land with different soil moisture or vegetation type resulting in "inland breezes" are also applicable to understanding sea breezes for small water body dimensions (Ookouchi et al. 1984; Segal et al. 1988; Mahrt et al. 1994; Courault et al. 2007). The intensity of inland breeze circulations caused by the difference in land-surface sensible heat fluxes between two land-surface types is typically weaker than a sea breeze, in part due to the enhanced turbulent mixing on the "moist" land side compared to the negligible thermal plumes noted over water (Segal and Arritt 1992; Yan and Anthes 1988). Small water bodies

Table 6 Summary of key results from numerical studies pertaining to water body dimensions $(d)$ and shoreline curvature $(r)$

\begin{tabular}{|c|c|c|}
\hline Study focus & Findings & References \\
\hline $\begin{array}{l}\text { Medium and large } \\
\text { water body } \\
\text { dimensions } \\
(d>50 \mathrm{~km})\end{array}$ & $\begin{array}{l}\text { Magnitude of } u, w, l \text { and } h \text { slowly in- } \\
\text { crease with increasing } d \text { for } d \text { between } \\
50-100 \mathrm{~km} \\
\text { Negligible dependence of sea breezes on } \\
d \text { greater than } 100 \mathrm{~km}\end{array}$ & $\begin{array}{l}\text { Physick (1976), Yan and Anthes (1988), } \\
\text { Segal et al. (1997), Boybeyi and } \\
\text { Raman (1992a), Savijarvi (1997) }\end{array}$ \\
\hline $\begin{array}{l}\text { Small water body } \\
\text { dimensions } \\
(d<50 \mathrm{~km})\end{array}$ & $\begin{array}{l}\text { Magnitude of } u, w, l \text { and } h \text { rapidly increase } \\
\text { with increasing } d \\
\text { Large shoreline curvature-induced } \\
\text { divergence and less available cool air } \\
\text { responsible for weaker sea-breeze for } \\
\text { small } d\end{array}$ & $\begin{array}{l}\text { Physick (1976), Neumann and Mahrer } \\
\text { (1975), Yan and Anthes (1988), Zhong } \\
\text { et al. (1991), Boybeyi and Raman } \\
\text { (1992a), Shen (1998) }\end{array}$ \\
\hline Curvature & $\begin{array}{l}\text { Convex shoreline strengthens sea breezes } \\
\text { Concave shoreline weakens sea breezes }\end{array}$ & $\begin{array}{l}\text { Mahrer and Segal (1985), McPherson } \\
\text { (1970), Arritt (1989), Gilliam et al. } \\
\text { (2004), Boybeyi and Raman (1992a) }\end{array}$ \\
\hline
\end{tabular}


Table 7 Summary of key results from numerical studies pertaining to terrain slope $(s)$ and terrain height $\left(h_{t}\right)$

\begin{tabular}{|c|c|c|}
\hline Study focus & Findings & References \\
\hline $\begin{array}{l}\text { Terrain slope/terrain } \\
\text { height }\end{array}$ & $\begin{array}{l}\text { Slope of sufficiently low steepness: } \\
\text { thermally-driven slope flows combine } \\
\text { with sea breezes to enhance } u, w, l \text { and } h \\
\text { Combined slope and sea breezes may lead } \\
\text { to earlier sea-breeze front passage } \\
\text { Slope of sufficiently high steepness: inland } \\
\text { penetration of SBF is suppressed and } u \text {, } \\
w, l \text { and } h \text { decrease } \\
\text { Distance between shoreline and mountain, } \\
\text { absolute height of mountain, length of } \\
\text { slope, } H \text {, and } N \text { are key factors in } \\
\text { determining critical slope angle }\end{array}$ & $\begin{array}{l}\text { Mahrer and Pielke (1977), Asai and } \\
\text { Mitsumoto (1978), Ookouchi et al. } \\
\text { (1978), Estoque and Gross (1981), } \\
\text { Kikuchi et al. (1981), Segal et al. } \\
\text { (1983), Neumann and Savijarvi (1986), } \\
\text { Ramis and Romero (1995), Miao et al. } \\
\text { (2003), Porson et al. (2007b) }\end{array}$ \\
\hline Other & $\begin{array}{l}\text { Channeling of sea breezes may locally } \\
\text { enhance } u, w \text {, and } l \\
\text { Small mountains inland from coast can } \\
\text { block inland penetration } \\
\text { Mountain slope can produce "chimney } \\
\text { effect" stalling sea-breeze front }\end{array}$ & $\begin{array}{l}\text { Ookouchi et al. (1978), Segal et al. } \\
\text { (1983), Neumann and Savijarvi (1986), } \\
\text { Lu and Turco (1994), Ramis and } \\
\text { Romero (1995), Millán et al. (2000), } \\
\text { Darby et al. (2002) }\end{array}$ \\
\hline
\end{tabular}

likely have boundary layers that are a hybrid between large-scale sea breezes and moist land situations.

Shoreline curvature $(r)$ can strongly affect interactions between the prevailing winds and sea breezes. A convex coastline yields convergence of the onshore low-level flow and strengthens the circulation, while a concave coastline weakens the circulation through divergence (McPherson 1970; Arritt 1989; Gilliam et al. 2004). The impact of the curvature associated with large and small circular lakes has been examined, with smaller lakes yielding more divergent circulations (Boybeyi and Raman 1992a). Baker et al. (2001) noted that shoreline curvature had a major impact on the location and timing of sea-breeze initiated precipitation.

\subsubsection{Terrain Height $\left(h_{t}\right)$ and Slope $(s)$}

Most numerical studies examining the influence of topography on sea breezes have been qualitative (Table 7). Topography can enhance sea breezes through elevated heating and cooling, which drives slope flows that combine with sea breezes, or suppress them by mechanically blocking the onshore flow (Atkinson 1981; Abbs and Physick 1992). The dependence of sea breezes on terrain is controlled by the terrain slope $(s)$, length of the terrain slope, terrain height $\left(h_{t}\right)$, location of the mountain relative to the coastline, and atmospheric stability. Although no study has looked systematically at the effects of terrain height on sea breezes, Porson et al. (2007b) were the first to systematically vary both atmospheric stability, slope angle and slope length. They found that $l$ and $h$ are highly dependent on both terrain slope and atmospheric stability.

Most numerical sea-breeze studies concerning terrain slope have focused on $u, w$, and $l$ (Table 7). These studies have found that on a heated slope of sufficiently low steepness (less than $2.29^{\circ}$ according to Asai and Mitsumoto 1978 or $\approx 0.8^{\circ}$ according to Porson et al. 2007b), thermally-driven slope flows may couple with sea breezes and increase $u, w, l$, and $h$ (Mahrer and Pielke 1977; Estoque and Gross 1981; Miao et al. 2003). Combined sea-breeze 
and slope flows may also lead to an earlier inland sea-breeze frontal passage (Ookouchi et al. 1978; Kikuchi et al. 1981). A slope of sufficiently high steepness will act to block the inland penetration of the sea-breeze front and decrease $u, w, l$, and $h$ (Asai and Mitsumoto 1978; Segal et al. 1983; Neumann and Savijarvi 1986; Porson et al. 2007b). The critical slope angle at which the coupling of thermally-driven slope flows outweighs the terrain blocking effects is variable and depends on the vertical stability profile, magnitude of slope heating (e.g., vegetation type, aspect), the total length of the slope, the distance from the coastline to the mountain, and the absolute height of the mountain. A secondary effect of topography on sea breezes is channelling, which can locally enhance $u, w$, and $l$ (Abbs 1986; Segal et al. 1997; Abbs and Physick 1992).

Darby et al. (2002) found that $l$ may occur on multiple scales depending on terrain height and distance inland of a mountain range. Miao et al. (2003) determined that $l$ was similar between "terrain" and "no-terrain" simulations while $h$ was enhanced. Asai and Mitsumoto (1978) and Lu and Turco (1994) suggest that upslope flows associated with topography located inland away from the coast do not readily couple with sea breezes compared to upslope flows associated with topography near the coast. However, even small mountains located some distance inland can act to block the late-afternoon inland acceleration of the sea-breeze front or remove its low-level baroclinicity (Ookouchi et al. 1978).

Lu and Turco (1994) and Millán et al. (2000) discuss topographic effects on pollutant transport, including the so-called "chimney effect" where coastal mountains stall the inland penetration of the sea-breeze front and set up a quasi-stationary region of upward vertical motion near the mountain crest. The coupling of sea breezes with slope flows in complex terrain makes the simple circulation cell illustrated in Fig. 2 inaccurate (Millán et al. 2000). Banta et al. (1993) observed sea breezes in complex terrain that did not have a return flow and hypothesized that slope flows provided the mass compensation normally provided by the return flow, although Miao et al. (2003) found that the presence of sloping terrain actually enhanced the magnitude of the return flow.

\subsubsection{Coriolis Parameter $(f)$}

Numerical studies of sea breezes have generally been conducted at fixed latitudes; consequently, knowledge of the effects of variations in latitude on sea breezes have been largely limited to observational comparisons and linear or scale analysis (e.g., Neumann 1977; Rotunno 1983). The Coriolis force, typically specified by the magnitude of the Coriolis parameter $(f)$, influences the wind direction and $l, u$, and $h$ of sea breezes.

The Coriolis force rotates the sea breeze $360^{\circ}$ over a 24-h period (Haurwitz 1947). Coriolis effects are small for most of the daytime lifecycle of sea breezes when friction and surface heating dominate (Yan and Anthes 1987). However, after about six hours from onset, sea breezes begin to rotate into a plane parallel to the coast and weaken due to the Coriolis force (Anthes 1978; Yan and Anthes 1987; Xian and Pielke 1991). The numerical scaling analyses of Tijm et al. (1999b) and Antonelli and Rotunno (2007) give further evidence on the increasing importance of $f$ during the latter stages of the sea-breeze lifecycle (Table 2). The magnitude of $u$ and surface friction modulate the influence of the Coriolis parameter for a given latitude. The Coriolis force may also interact with $w$ and shoreline shape to determine areas of breeze-induced convergence (Boybeyi and Raman 1992a).

The Coriolis force primarily affects $l$ and $u$. Yan and Anthes (1987) studied the effects of variations in the Coriolis parameter at latitudes of 20,30 , and $45^{\circ} \mathrm{N}$ and found results consistent with the linear analysis of Rotunno (1983) (Eq. 2). In the absence of friction, $l$ was less (more) than $100 \mathrm{~km}$ from the coast and in (out) of phase with the diurnal heating poleward 
(equatorward) of $30^{\circ}$ latitude. They hypothesized that land breezes at high latitudes may result more from the rotation of sea breezes by the Coriolis force than the reversing diurnal pressure gradient. For locations in a high land-surface sensible heat flux, low latitude environment, the small Coriolis force may still be critical. Garratt and Physick (1985) found sea breezes at $15^{\circ} \mathrm{S}$ latitude had inertial periods of approximately $46 \mathrm{~h}$, allowing for very slow turning of the winds and the extreme $l$ observed in Australia.

\subsubsection{Surface Roughness Length $\left(z_{o}\right)$}

Frictional drag acts to destroy the developing horizontal pressure gradient associated with sea breezes (Anthes 1978). Frictional effects are induced by both surface roughness and turbulent motions (e.g., convection and Kelvin-Helmholtz instability), and while the aerodynamic roughness length $\left(z_{o}\right)$ has a large influence on the developing circulation, the dependence of sea breezes on the observed ranges of roughness length associated with different land types and land-water surface contrasts is generally small (Neumann and Mahrer 1975; Savijarvi and Alestalo 1988; Arritt 1989; Yang 1991; Boybeyi and Raman 1992a; Tijm et al. 1999b). Spatial perturbations in the roughness length (i.e., subgrid-scale variability in most modelling studies) have also been found to have little effect in ensemble-mean sea-breeze statistics (Garratt et al. 1990). Numerical investigations of sea breezes for the most part specify constant roughness lengths over land and water surfaces. Specified roughness lengths for studies listed in Table 1 range between $0.04-0.5 \mathrm{~m}$ over land and $0-0.2 \mathrm{~mm}$ over water. However, more recent numerical modelling by Courault et al. (2007) and linear scaling by Drobinski and Dubos (2009) show that the roughness length helps to control $h$ for small inland-breeze type circulations. Boybeyi and Raman (1992a) found that increasing roughness length resulted in an enhanced circulation with a larger vertical transfer of heat, while Kala et al. (2010) found that decreasing roughness length resulted in higher surface winds and increased surface moisture advection. Surface friction also influences the formation of clef and lobe instability caused by horizontal convective rolls (Dailey and Fovell 1999).

\section{Discussion}

\subsection{Modelling Limitations and Comparison with Observations}

The majority of numerical studies concerning sea breezes were conducted using two-dimensional hydrostatic models. The differences between hydrostatic versus non-hydrostatic simulations are typically small when the model horizontal grid spacing is larger than $1 \mathrm{~km}$ (Avissar et al. 1990), and, because non-hydrostatic effects act to weaken mature sea breezes, hydrostatic models may overestimate sea-breeze intensity (Martin and Pielke 1983). The modelled vertical velocities and frontal structure in most hydrostatic simulations are understandably poor (Avissar et al. 1990). Although the use of three-dimensional models is important to realistically simulate planetary boundary-layer (PBL) turbulence and the interactions between horizontal convective rolls and other small-scale PBL features associated with sea breezes, two-dimensional simulations are adequate for many idealized simulations.

Many numerical simulations of sea breezes have been conducted with horizontal grid spacing greater than $2 \mathrm{~km}$ in combination with lower-order PBL turbulence parametrisations (Table 1). Inadequate treatment of PBL turbulence may be the largest deficiency of many early numerical models of sea breezes (Briere 1987; Yang 1991), and may be the reason that most numerical simulations are unable to reproduce the observed afternoon slowing of the 
sea-breeze front associated with turbulent frontolysis (Simpson et al. 1977). Increasing the horizontal resolution of numerical simulations or using more sophisticated PBL parametrisation schemes does not always yield improved results, as the increase in resolution may be insufficient to significantly improve the resolved turbulence in the PBL (Colby 2004; Novak and Colle 2006; Srinivas et al. 2007).

It is beyond the scope of this review to conduct a thorough comparison between numerical and observational results. On average, model estimates of $u, l$, and $h$ differed from observations by around $25 \%$ for those studies listed in Table 1 and for which it is possible to make such comparisons. The basic structures of sea breezes are well-represented in most cases, but the fine-scale features and interactions between the sea breeze and the geophysical variables are generally not captured. Consequently, it is not surprising that most numerical simulations were deficient in predicting the frontal intensity, $l$, and $w$.

Relating numerical experiments in which only a single variable is perturbed to the constantly evolving atmosphere is difficult. Despite this constraint, the scaling of observational datasets provides the most comprehensive observational evidence of the effects of geophysical variables on sea breezes. The observational scaling analyses by Steyn (1998, 2003), and Kruit et al. (2004) investigate the effects of the land-surface sensible heat flux, atmospheric stability, and Coriolis parameter on sea breezes. Their results generally agree with the numerical scaling by Porson et al. (2007a) and Antonelli and Rotunno (2007) (Table 2), with some differences possibly attributable to the unique local characteristics of the observational datasets used. A general increase in the characteristic sea-breeze speed and length scales is noted in dry areas or low latitudes that typically observe high daytime surface sensible heat fluxes compared to regions that observe low daytime surface sensible heat fluxes (Atkinson 1981; Kruit et al. 2004). Observational studies also reinforce the numerical findings of the effects of the ambient geostrophic wind on sea breezes. A decrease in $l$ and $h$ and an increase in $w$ and temperature gradient across the sea-breeze front have all been observed for the case of moderate offshore winds (Simpson et al. 1977; Zhong and Takle 1993; Atkins et al. 1995; Helmis et al. 1995; Melas et al. 1998; Asimakopoulos et al. 1999; Chiba et al. 1999). Observations of sea breezes near lakes of different sizes also corroborate the numerical findings that generally weaker sea breezes occur with smaller lake dimensions (Bitan 1977; Atkinson 1981; Segal et al. 1997; Sun et al. 1997; Samuelsson and Tjernstrom 2001). Observations have shown the continuation of tropical sea breezes at night due to a lack of turning of the wind by the Coriolis force. The coupling of slope and sea-breeze circulations has also been observed (Atkinson 1981; Abbs 1986; Banta et al. 1993; Mastrantonio et al. 1994).

\subsection{Recent High-resolution Studies}

Since 1990, a number of two- and three-dimensional idealized numerical studies have been made at a horizontal grid spacing of approximately $100 \mathrm{~m}$, where most boundary-layer turbulence is explicitly resolved (e.g, Hadfield et al. 1991, 1992; Sha et al. 1991, 1993, 2004; Fovell and Dailey 2001; Letzel and Raasch 2003; Antonelli and Rotunno 2007; Cunningham 2007; Talbot et al. 2007). These large-eddy simulations (LES) provide insight into the fine-scale structure of sea breezes and interactions between sea breezes and boundary-layer features, such as lobe and cleft instabilities and horizontal convective rolls (Fig. 5). Observational studies have corroborated the horizontally non-uniform structure and oscillatory propagation speed of the sea-breeze front simulated by models run at high resolution (Yoshikado 1990; Wakimoto and Atkins 1994; Wood et al. 1999; Stephan et al. 1999; Puygrenier et al. 2005). A number of air pollution dispersion models have simulated the "translocation" or significant vertical advection of pollutants by narrow frontal plumes, the effect of the 


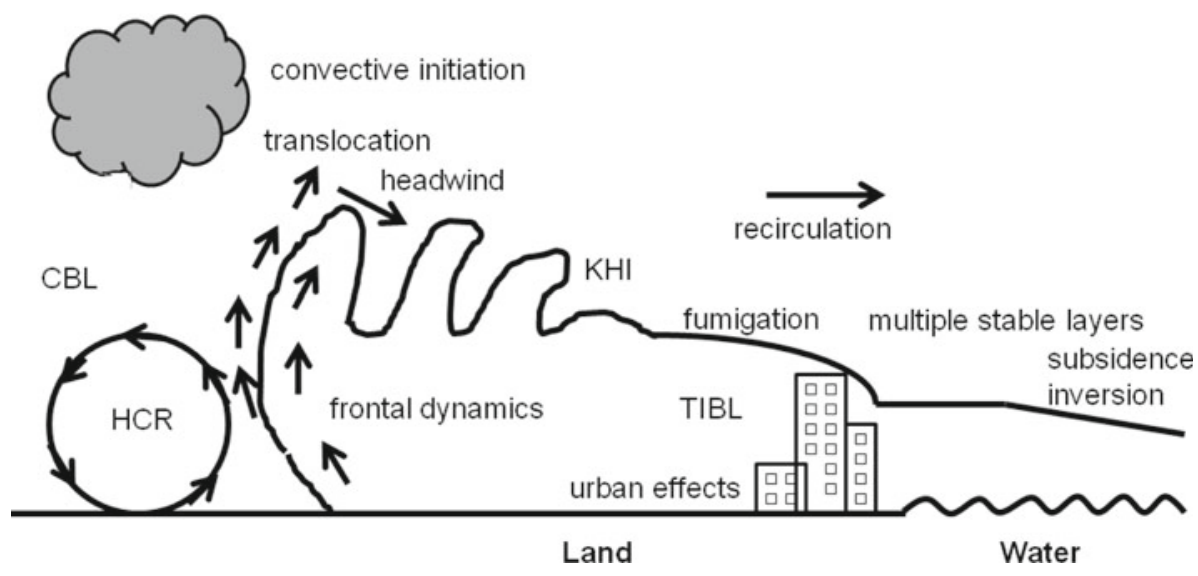

Fig. 5 Recent topics of interest in high-resolution numerical modelling studies of sea breezes including: horizontal convective roll (HCR), convective boundary layer (CBL), Kelvin-Helmholtz instability (KHI), and the thermal internal boundary layer (TIBL)

convective internal boundary layer on pollutant fumigation, interactions between urbaninduced circulations and sea breezes, and the effects of turbulence and multilayer stratification on recirculation (Lemonsu et al. 2006; Thompson et al. 2007).

A number of recent studies have investigated the interactions between horizontal convective rolls and the sea-breeze front. Dailey and Fovell (1999) found that the sea-breeze front developed considerable three-dimensional variability in the presence of horizontal convective rolls oriented perpendicular to the sea-breeze front, while frontal uplift and propagation speed were influenced by interactions with horizontal convective rolls oriented parallel to the seabreeze front. Weak lift associated with sea breezes was found to be important for convective initiation by Fovell (2005). Kelvin-Helmholtz instability billows are also another important fine-scale feature behind the sea-breeze front that may trigger or enhance convection, redistribute pollutants, and induce a top-friction force that slows the sea-breeze front's inland progression (Rao et al. 1999; Rao and Fuelberg 2000; Plant and Keith 2007). Ogawa et al. (2003) modelled periodic turbulent frontolysis and associated discontinuous frontal structures associated with Rayleigh-Bernard convection, and with the exception of Antonelli and Rotunno (2007), numerical constraints have prevented LES studies from investigating the dependence of sea breezes on the various geophysical variables. Thus, as computational capabilities improve, there is a need to revisit many of the earlier numerical studies at LES resolution.

\subsection{The Dependence of Sea Breezes on Geophysical Variables}

All ten geophysical variables listed in this study affect the characteristics of sea breezes. The fundamental driver of sea breezes is the differential sensible heating between the land and water surfaces, and variations in land-surface sensible heat flux, background geostrophic wind, and atmospheric stability have a pronounced effect on the intensity of sea breezes at a given location, while water body dimensions, Coriolis force, terrain height and terrain slope may explain differences in sea breezes around the world. The impacts of shoreline curvature, roughness length and atmospheric moisture on sea breezes are generally smaller.

As a way to assess the relative impacts of these variables, we summarize in Table 8 the fractional change (i.e., change divided by original value) in the length and velocity scales 
Table 8 Impact of a 100\% increase in the geophysical variables on the mid-afternoon sea-breeze length and velocity scales expressed as the fractional change (change divided by original value)

\begin{tabular}{|c|c|c|c|c|c|}
\hline $\begin{array}{l}100 \% \text { increase } \\
\text { in }\end{array}$ & $\begin{array}{l}\% \text { change } \\
u_{\max }\end{array}$ & $\begin{array}{l}\% \text { change } \\
w_{\max }\end{array}$ & $\begin{array}{l}\text { change } \% \\
l_{\max }\end{array}$ & $\begin{array}{l}\text { change \% } \\
h\end{array}$ & Reference \\
\hline \multicolumn{6}{|c|}{ Temporally-dependent geophysical variables } \\
\hline \multirow[t]{5}{*}{$H$} & - & - & $15-100$ & - & Physick (1980), Tijm et al. (1999b) \\
\hline & 30 & 25 & 25 & - & Troen (1982) \\
\hline & 64 & 80 & - & - & Shen (1998) \\
\hline & 80 & 200 & 30 & 30 & Miao et al. (2003) \\
\hline & $30-40$ & - & 40 & 35 & $\begin{array}{l}\text { Antonelli and Rotunno (2007), } \\
\text { Porson et al. (2007a) }\end{array}$ \\
\hline \multirow[t]{3}{*}{$V_{g}: 1 \rightarrow 2 \mathrm{~ms}^{-1}$ offshore } & 10 & 25 & -50 & -5 & Arritt (1993) \\
\hline & - & - & -15 & - & Savijarvi and Alestalo (1988) \\
\hline & - & - & -40 & - & Tijm et al. (1999b) \\
\hline \multirow[t]{3}{*}{$V_{g}: 3 \rightarrow 6 \mathrm{~ms}^{-1}$ offshore } & -5 & -10 & - & -50 & Arritt (1993) \\
\hline & - & - & -125 & - & Porson et al. (2007c) \\
\hline & - & - & -100 & - & Savijarvi and Alestalo (1988) \\
\hline$V_{g}: 1 \rightarrow 2 \mathrm{~ms}^{-1}$ onshore & -25 & -25 & - & - & Arritt (1993) \\
\hline \multirow[t]{4}{*}{$N$} & -10 & -10 & -5 & -75 & Troen (1982) \\
\hline & -15 & - & 0 & -40 & Arritt (1989) \\
\hline & -25 & -50 & - & - & Yang (1991) \\
\hline & - & - & - & -100 & $\begin{array}{l}\text { Antonelli and Rotunno (2007), } \\
\text { Porson et al. (2007a) }\end{array}$ \\
\hline \multicolumn{6}{|c|}{ Location-dependent geophysical variables } \\
\hline$d: 10 \rightarrow 20 \mathrm{~km}$ & 75 & - & - & - & Segal et al. (1997) \\
\hline$d: 25 \rightarrow 50 \mathrm{~km}$ & $25-35$ & 100 & - & - & $\begin{array}{l}\text { Segal et al. (1997), Neumann and } \\
\text { Mahrer (1975), Boybeyi and Ra- } \\
\text { man (1992a,b) }\end{array}$ \\
\hline$d: 50 \rightarrow 100 \mathrm{~km}$ & $10-20$ & 100 & - & - & Segal et al. (1997), Physick (1976) \\
\hline$f: 0^{\circ} \rightarrow 20^{\circ}$ & 40 & - & 25 & - & Yan and Anthes (1987) \\
\hline$f: 20^{\circ} \rightarrow 45^{\circ}$ & 100 & - & 200 & - & Yan and Anthes (1987) \\
\hline$f: 20^{\circ} \rightarrow 45^{\circ}$ & 5 & 100 & - & - & Yang (1991) \\
\hline \multirow[t]{2}{*}{$z_{o}$} & 0 & - & 0 & - & $\begin{array}{l}\text { Savijarvi and Alestalo (1988), } \\
\text { Tijm et al. (1999b) }\end{array}$ \\
\hline & 1 & 5 & - & - & Yang (1991) \\
\hline \multirow[t]{2}{*}{$s:$ No slope $\rightarrow$ slope } & 100 & & 200 & & $\begin{array}{l}\text { Asai and Mitsumoto (1978), } \\
\text { Kikuchi et al. (1981) }\end{array}$ \\
\hline & 15 & 200 & 0 & 20 & Miao et al. (2003) \\
\hline
\end{tabular}

Arrow $(\rightarrow$ ) denotes a specific doubling of a geophysical variable

of sea breezes to $100 \%$ increases in the magnitudes of the geophysical variables. In general, most studies agree on the sign of the observed sensitivity of sea breezes to variations in a given geophysical variable. However, the magnitude of that dependence can vary widely between studies.

Of the ten geophysical variables, the effects of variations in land-surface sensible heat flux and geostrophic wind on sea-breeze speed and length scales are the most widely studied and quantified (Table 8). All studies agree that higher values of land-surface sensible heat flux are associated with stronger, deeper sea breezes. There is poor agreement outside of the 
scaling studies (Table 2) as to the magnitude of the effects of variations in the land-surface sensible heat flux on $u$ and $w$. Despite the fact that simulations with a horizontal grid spacing greater than $1 \mathrm{~km}$ do not fully resolve vertical motions associated with the sea-breeze front, $w$ is very sensitive in some studies to variations in land-surface sensible heat flux, presumably due to changes in convective thermals near the sea-breeze front. There is better agreement that $l$ and $h$ both increase by around $25-50 \%$ for a $100 \%$ increase in the land-surface sensible heat flux.

The magnitude of the geostrophic wind modulates $l$ and $h$, and as shown in Fig. 4 , the presence of an offshore geostrophic wind of $2 \mathrm{~m} \mathrm{~s}^{-1}$ delays the onshore arrival of the seabreeze front by up to several hours and changes $l$ by up to 50\% (Physick 1980; Tijm et al. $1999 \mathrm{~b})$. Variations in the magnitude of the offshore geostrophic wind affect $l$ more strongly than $u, w$, and $h$ in most studies (Table 8). Increasing offshore geostrophic winds from 1 to $2 \mathrm{~m} \mathrm{~s}^{-1}$ results in a 10-25\% increase in $u$ and $w$ associated with convergent frontogenesis, while any further increase in the offshore geostrophic winds from 3 to $6 \mathrm{~m} \mathrm{~s}^{-1}$ results in a 5-10\% decrease in the magnitude of $u$ and $w$, and doubling the offshore geostrophic wind from 3 to $6 \mathrm{~m} \mathrm{~s}^{-1}$ greatly reduces the extent of inland penetration.

Stability, besides indirectly modulating the effects of topography, geostrophic wind, and other geophysical variables, has its largest impact on the vertical scale of the circulation, with a $100 \%$ increase in stability resulting in a 40-100\% decrease in $h$ and a $10-50 \%$ decrease in $w$. The modelling results reveal only slight decreases in $u$ and $l$ associated with a doubling of stability, providing some evidence that linear theory may overestimate the impacts of changes in stability on $l$.

There are only a handful of studies that quantify the effects of water body dimensions on sea breezes, and these only discuss the speed scales. Increasing the dimensions of a water body from 25 to $50 \mathrm{~km}$ yields roughly a $30 \%$ increase in $u$, while increasing the water body dimensions further from 50 to $100 \mathrm{~km}$ only results in another $\approx 15 \%$ increase in $u$. Although $w$ is quite sensitive to changes in water body dimensions-a $100 \%$ increase in water body dimensions results in a doubling of vertical velocities - it is unclear why changes in $w$ do not decrease for larger lakes sizes in a similar fashion as for $u$.

The effect of the Coriolis force on late afternoon sea-breeze strength is significant (Coriolis effects are minimal through the early afternoon hours), and increases with increasing latitude (Yan and Anthes 1987). Terrain slope forcing on sea breezes is difficult to compare since each study used unique combinations of terrain height and slope. Simulations with mountains yield small (15-20\%) to large (100-200\%) increases in the magnitude of $u, w, h$, and $l$ compared to when they are removed.

\subsection{Gaps in Understanding and Recommendations for Future Research}

Despite the extensive number of scientific studies devoted to understanding the influence of geophysical parameters on sea breezes, gaps remain, and are largely due to numerical and computational limitations such that a limited range of parameter values have been examined. For example, most studies used values of land-surface sensible heat flux typical of those observed during mid-latitude summer. Testing the interdependence or feedbacks that may exist between the geophysical variables has generally not been feasible. Horizontal grid spacing greater than $2 \mathrm{~km}$ used in most numerical simulations has limited the realism of the vertical motion field and a wide array of boundary-layer interactions. An extended analysis of the evolution of sea breezes in the context of both time of day and the temporal evolution of the geophysical variables (i.e., sensible heat flux or background winds) is needed. The geophysical variables are clearly not temporally invariant as many numerical studies have 
chosen to assume. Further work on the dependence of sea breezes on sets of basic configurations of water body dimensions, the area of heated land-surface, coastline geometry, and surrounding topography is warranted. A better understanding of the effects of the geophysical variables on the sea-breeze speed and depth scales inland from the coastline is also needed. For example, Garratt and Physick (1985) found that the depth of the sea-breeze gravity current inland from the Australian coast varied between 550 and $1650 \mathrm{~m}$ during the expansion and contraction of the convective boundary layer.

In addition to these larger concerns, there are a number of specific research questions that remain unanswered and are briefly mentioned here. Despite the widespread occurrence of stable layers in the marine boundary layer, most numerical studies used idealized standard atmospheric temperature profiles. Hence, incorporating realistic vertical stability profiles and examining further the feedbacks between stability and the other geophysical variables is quite important. Initiation of sea breezes remains a topic for further investigation since three different possible explanations for the formation of sea-breeze horizontal pressure gradients are presented by Tijm and Van Delden (1999). Given that hodograph rotation has been largely neglected since the early study of Haurwitz (1947), simulating the hodograph rotation under a wide array of geophysical variables is a topic for future exploration. Steyn and Kallos (1992) found that anticlockwise rotation of the sea-breeze hodograph occurred (opposite the typical Coriolis-induced clockwise rotation) due to terrain effects. Improved understanding of how geophysical variables influence vertical velocities and the fine-scale structure and propagation of the sea-breeze front is needed now that numerical simulations are able to accurately simulate the fine-scale frontal structure. Very little research has been conducted on the effects of the geophysical variables on the return current or return-return current, over water subsidence, or convective initiation. Finally, the presence of a sea-breeze "precursor" noted in some observational studies (Banta et al. 1993; Mastrantonio et al. 1994) has not been numerically simulated to our knowledge.

The results of this survey point out a number of areas where future research could benefit pollutant transport studies. Reducing the surface concentration of pollutants trapped within sea breezes is most readily accomplished by increasing $h$ and $w$, allowing increased vertical mixing. Improved understanding of how stability, geostrophic winds, and terrain influence offshore subsidence and pollutant recirculation is needed. The importance of sea-breeze frontogenesis and interactions between sea breezes and a host of boundary-layer features (e.g., Kelvin-Helmholtz instability and horizontal convective rolls) in transporting and removing pollutants from the sea-breeze circulation remains an active area of interest.

As discussed by Shaw et al. (2009), wind power resources in coastal regions are dependent on the magnitude of the sea-breeze flow. A topic for further study concerns the upper limit to wind speeds in high sensible heat flux environments as a result of turbulent frontolysis. Analysis of the wind resource offshore over open water under a wide range of the geophysical variables is needed. For example, the shifting of the sea-breeze circulation by the geostrophic flow may enhance the low-level winds in the immediate offshore zone. Surface roughness effects also need to be revisited under a wide array of atmospheric conditions; Garvine and Kempton (2008) found that wind speeds at hub height were three times higher over the open shelf waters than along the shore.

Acknowledgements This study was supported by the National Aeronautics and Space Administration headquarters under the Earth and Space Science Fellowship program-Grant "08-Earth08R-5" and by the National Science Foundation project entitled "Lake Breeze System of the Great Salt Lake" Grant \# ATM-0802282. We gratefully acknowledge the input of three anonymous reviewers, which significantly improved the paper. 
Open Access This article is distributed under the terms of the Creative Commons Attribution Noncommercial License which permits any noncommercial use, distribution, and reproduction in any medium, provided the original author(s) and source are credited.

\section{References}

Abbs DJ (1986) Sea-breeze interactions along a concave coastline in Southern Australia: observations and numerical modeling study. Mon Weather Rev 114:831-848

Abbs DJ, Physick WL (1992) Sea-breeze observations and modelling: a review. Aust Meteorol Mag 41:7-19

Ado HY (1992) Numerical study of the daytime urban effect and its interaction with the sea-breeze. J Appl Meteorol 31:1146-1164

Alpert P, Cohen A, Neumann J, Doron E (1982) A model simulation of the summer circulation from the Eastern Mediterranean past Lake Kinneret in the Jordan Valley. Mon Weather Rev 110:994-1006

Anthes RA (1978) The height of the planetary boundary layer and the production of circulation in a sea breeze model. J Atmos Sci 35:1231-1239

Antonelli M, Rotunno R (2007) Large-eddy simulation of the onset of the sea breeze. J Atmos Sci 64:44454457

Arritt RW (1987) The effect of water surface temperature on lake breezes and thermal internal boundary layers. Boundary-Layer Meteorol 40:101-125

Arritt RW (1989) Numerical modelling of the offshore extent of sea breezes. Q J Roy Meteorol Soc 115:547570

Arritt RW (1993) Effects of the large-scale flow on characteristic features of the sea breeze. J Appl Meteorol 32:116-125

Asai T, Mitsumoto S (1978) Effects of an inclined land surface on the land and sea breeze circulation: a numerical experiment. J Meteorol Soc Jpn 56:559-570

Asimakopoulos DN, Helmis CG, Papadopoulos KH, Kalogiros AJ, Kassomenos P, Petrakis M (1999) Inland penetration of sea breeze under opposing offshore wind. Meteorol Atmos Phys 79:97-110

Atkins NT, Wakimoto RM, Weckwerth TM (1995) Observations of the sea-breeze front during CaPE. Part II: dual-doppler and aircraft analysis. Mon Weather Rev 123:944-969

Atkinson BW (1981) Meso-scale atmospheric circulations. Academic Press, London, 495 pp

Avissar R, Moran MD, Wu G, Meroney RN, Pielke RA (1990) Operating ranges of mesoscale numerical models and meteorological wind tunnels for the simulation of sea and land breezes. Boundary-Layer Meteorol 50:227-275

Baker RD, Lynn BH, Boone A, Tao WK, Simpson J (2001) The influence of soil moisture, coastline curvature, and land-breeze circulations on sea-breeze-initiated precipitation. J Hydrometeorol 2:193-211

Banta RM, Olivier LD, Levinson DH (1993) Evolution of the Monterey Bay sea-breeze layer as observed by pulsed Doppler radar. J Atmos Sci 50:3959-3982

Bechtold P, Pinty JP, Mascart P (1991) A numerical investigation of the influence of large-scale winds on sea-breeze and inland-breeze type circulations. J Appl Meteorol 30:1268-1279

Biggs WG, Graves ME (1962) A lake breeze index. J Appl Meteorol 1:474-480

Bitan A (1977) The influence of the special shape of the Dead Sea and its influence on the local wind system. Arch Met Geoph Biokl 24:283-301

Briere S (1987) Energetics of daytime sea breeze circulation as determined from a two-dimensional, thirdorder turbulence closure model. J Atmos Sci 44:1455-1474

Boybeyi Z, Raman S (1992a) A three-dimensional numerical sensitivity study of mesoscale circulations induced by circular lakes. Meteorol Atmos Phys 49:19-41

Boybeyi Z, Raman S (1992b) A three-dimensional numerical sensitivity study of convection over the Florida peninsula. Boundary-Layer Meteorol 60:325-359

Buckley RL, Kurzeja RJ (1997) An observational and numerical study of the nocturnal sea breeze. Part I: structure and circulation. J Appl Meteorol 36:1577-1598

Cai XM, Steyn DG (2000) Modelling study of sea breezes in a complex coastal environment. Atmos Environ $34: 2873-2885$

Cenedese AM, Miozzi AM, Monti P (2000) A laboratory investigation of land and sea breeze regimes. Exp Fluids 29:291-299

Chen JM, Oke TR (1994) Mixed layer heat advection and entrainment during the sea breeze. Boundary-Layer Meteorol 68:139-158 
Cheng FY, Byun DW (2008) Application of high resolution land use and land cover data for atmospheric modelling in the Houston-Galveston metropolitan area. Part I: meteorological simulation results. Atmos Environ 42:7795-7811

Chiba O, Kobayashi F, Naito G, Sassa K (1999) Helicopter observations of the sea breeze over a coastal area. J Appl Meteorol 38:481-492

Clappier A, Martilla A, Grossi P, Thunis P, Pasi F, Krueger BC, Calpini B, Graziani G, van den Bergh H (2000) Effect of sea breeze on air pollution in Greater Athens area. Part I: numerical simulations and field observations. J Appl Meteorol 39:546-562

Clarke RH (1984) Colliding sea-breezes and the creation of internal atmospheric bore waves: two-dimensional numerical studies. Aust Meteorol Mag 32:207-226

Colby FP (2004) Simulation of the New England sea breeze: the effect of grid spacing. Weather Forecast 19:277-285

Courault D, Drobinski P, Brunet Y, Lacarrere P, Talbot C (2007) Impact of surface heterogeneity on a buoyancy-driven convective boundary layer in light winds. Boundary-Layer Meteorol 124:383-403

Cunningham PS (2007) Idealized numerical simulations of the interactions between buoyant plumes and density currents. J Atmos Sci 64:2105-2115

Daggupaty S (2001) A case study of the simultaneous development of multiple lake-breeze fronts with a boundary layer forecast model. J Appl Meteorol 40:289-311

Dailey PS, Fovell RG (1999) Numerical simulation of the interaction between the sea breeze front and horizontal convective rolls. Part I: offshore ambient flow. Mon Weather Rev 127:858-878

Dalu GA, Pielke RA (1989) An analytical study of the sea breeze. J Atmos Sci 46:1815-1825

Dandou A, Tombrou M, Soulakellis N (2009) The influence of the City of Athens on the evolution of the sea-breeze front. Boundary-Layer Meteorol 131:35-51

Darby LS, Banta RM, Pielke RA (2002) Comparisons between mesoscale model terrain sensitivity studies and doppler lidar measurements of the sea breeze at Monterey Bay. Mon Weather Rev 12:2813-2838

Drobinski P, Dubos T (2009) Linear breeze scaling: from large-scale land/sea breezes to mesoscale inland breezes. Q J Roy Meteorol Soc 135:1766-1775

Drobinski P, Bastin S, Dabas A, Delville P, Reitebuch O (2006) Variability of three-dimensional sea breeze structure in southern France: observations and evaluation of empirical scaling laws. Ann Geophys 24:1783-1799

Durand P, Druilhet A, Briere S (1989) A sea-land transition observed during the COAST experiment. J Atmos Sci 46:96-116

Estoque MA (1961) A theoretical investigation of the sea breeze. Q J Roy Meteorol Soc 87:136-146

Estoque MA (1962) The sea breeze as a function of the prevailing synoptic situation. J Atmos Sci 19:244-250

Estoque MA, Gross JM (1981) Further studies of a lake breeze. Part 1l: theoretical study. Mon Weather Rev 109:619-634

Estoque MA, Gross JM, Lai H (1976) A lake breeze over Southern Lake Ontario. Mon Weather Rev 104:386396

Feliks Y (1993) A numerical model for estimation of the diurnal fluctuation of the inversion height due to the sea-breeze. Boundary-Layer Meteorol 62:151-161

Finkele K (1998) Inland offshore propagation speeds of a sea breeze from simulations and measurements. Boundary-Layer Meteorol 87:307-329

Finkele K, Hacker JM, Kraus H, Byron-Scott RAD (1995) A complete sea-breeze circulation cell derived from aircraft observations. Boundary-Layer Meteorol 73:299-317

Fisher EL (1961) A theoretical study of the sea breeze. J Atmos Sci 18:216-233

Fovell RG (2005) Convective initiation ahead of the sea breeze front. Mon Weather Rev 133:264-278

Fovell RG, Dailey PS (2001) Numerical simulation of the interaction between the sea breeze front and horizontal convective rolls. Part II: alongshore ambient flow. Mon Weather Rev 129:2057-2072

Franchito SH, Rao VB, Stech JL, Lorenzzetti JA (1998) The effect of coastal upwelling at Cabo Frio, Brazil: a numerical experiment. Ann Geophys 16:866-881

Franchito SH, Oda TO, Rao VB, Kayano MT (2008) Interaction between coastal upwelling and local winds at Cabo Frio, Brazil: an observational study. J Appl Meteorol Climatol 47:1590-1598

Freitas ED, Rozoff CM, Cotton WM, Silva Dias PL (2007) Interactions of an urban heat island and sea breeze circulations during winter over the metropolitan area of Sao Paulo, Brazil. Boundary-Layer Meteorol 122:43-65

Garratt JR (1990) The internal boundary layer-a review. Boundary-Layer Meteorol 50:171-203

Garratt JR, Physick WL (1985) The inland boundary layer at low latitudes II: sea-breeze influences. Boundary-Layer Meteorol 33:209-231

Garratt JR, Pielke RA, Miller WF, Lee TJ (1990) Mesoscale model response to random surface-based perturbations - a sea-breeze experiment. Boundary-Layer Meteorol 52:313-334 
Garvine RW, Kempton W (2008) Assessing the wind field over the continental shelf as a resource for electric power. J Mar Res 66:751-773

Gilliam RC, Raman S, Niyogi DDS (2004) Observational and numerial study on the influence of large-scale flow direction and coastline shape on sea-breeze evolution. Boundary-Layer Meteorol 111:275-300

Grisogono B, Strom L, Tjernstrom M (1998) Small scale variability in the atmospheric boundary layer. Boundary-Layer Meteorol 88:23-46

Hadfield MG, Cotton WR, Pielke RA (1991) Large-eddy simulation of thermally forced circulations in the convective boundary layer. Part I: a small scale circulation with zero wind. Boundary-Layer Meteorol 57:79-114

Hadfield MG, Cotton WR, Pielke RA (1992) Large-eddy simulation of thermally forced circulations in the convective boundary layer. Part II: the effect of changes in wavelength and wind speed. Boundary-Layer Meteorol 58:307-327

Hara T, Ohda Y, Uchida T, Obha R (2009) Wind-tunnel and numerical simulations of the coastal thermal internal boundary layer. Boundary-Layer Meteorol 130:365-381

Helmis CG, Papadopoulos KH, Kalagiros JA, Soilemes AT, Asimakopoulos DN (1995) Influence of background flow on evolution of Saronic Gulf sea breeze. Atmos Environ 29:3689-3701

Harris L, Kotamarthi VR (1995) The characteristics of the Chicago lake breeze and its effects on trace particle transport: results from an episodic event simulation. J Appl Meteorol 44:1637-1654

Haurwitz B (1947) Comments on the sea-breeze circulation. J Atmos Sci 4:1-8

Hinrichsen D (1999) Coastal waters of the world: trends, threats, and strategies. Island Press, Washington, DC, 298 pp

Kala J, Lyons TJ, Abbs DJ, Nair US (2010) Numerical simulations of the impacts of land-cover change on a southern sea breeze in south-west western Australia. Boundary-Layer Meteorol 135:485-503

Kikuchi Y, Arakawa S, Kimura F, Shirasaki K, Nagano Y (1981) Numerical study on the effects of mountains on the land and sea breeze circulation in the Kanto district. J Meteorol Soc Jpn 59:723-738

Kusaka H, Kimura F, Hirakuchi H, Mizutori M (2000) The effects of land-use alteration on the sea breeze and daytime heat island in the Tokyo metropolitan area. J Meteorol Soc Jpn 78:405-420

Kuwagata T, Kondo J, Sumioka (1994) Thermal effect of the sea breeze on the structure of the boundary layer and the heat budget over land. Boundary-Layer Meteorol 67:119-144

Kruit RJW, Holtslag AAM, Tijm ABC (2004) Scaling of the sea-breeze strength with observations in the Netherlands. Boundary-Layer Meteorol 112:369-380

Letzel MO, Raasch S (2003) Large eddy simulation of thermally induced oscillations in the convective boundary layer. J Atmos Sci 60:2328-2341

Lambert S (1974) High resolution numerical study of the sea-breeze front. Atmosphere 12:97-105

Lemonsu A, Bastin S, Masson V, Drobinski P (2006) Vertical structure of the urban boundary over Marseille under sea-breeze conditions. Boundary-Layer Meteorol 118:477-501

Levitin J, Kambezidis HD (1997) Numerical modelling of the thermal internal boundary-layer evolution using Athens field experimental data. Boundary-Layer Meteorol 84:207-217

Levy I, Dayan U, Mahrer Y (2008) Studying coastal recirculation with a simplified analytical land-sea breeze model. J Geophys Res 113:D03104

Levy I, Mahrer Y, Dayan U (2009) Coastal and synoptic recirculation affecting air pollutants dispersion: a numerical study. Atmos Environ 43:1991-1999

Liu H, Chan JCL, Cheng AYS (2001) Internal boundary layer structure under sea breeze conditions in Hong Kong. Atmos Environ 35:683-692

Lu R, Turco RP (1994) Air pollutant transport in a coastal environment. Part I: two-dimensional simulations of sea-breeze and mountain effects. J Atmos Sci 51:2285-2308

Magata M (1965) A study of the sea breeze by the numerical experiment. Pap Meteorol Geophys 16:23-36

Mahrer Y, Pielke RA (1976) Numerical simulation of the airflow over Barbados. Mon Weather Rev 104:13921402

Mahrer Y, Pielke RA (1977) The effects of topography on sea and land breezes in a two-dimensional numerical model. Mon Weather Rev 105:1151-1162

Mahrer Y, Segal M (1985) On the effects of islands' geometry and size on inducing sea breeze circulation. Mon Weather Rev 113:170-174

Mahrt L, Sun J, Vickers D, Macpherson JI, Pederson JR, Desjardins RL (1994) Observations of fluxes and inland breezes over a heterogeneous surface. J Atmos Sci 51:2484-2499

Mak MK, Walsh JE (1976) On the relative intensities of sea and land breezes. J Atmos Sci 33:242-251

Marshall CH, Pielke RA, Steyaert LT, Willard DA (2004) The impact of anthropogenic land-cover change on the Florida peninsula sea breezes and warm season sensible weather. Mon Weather Rev 132:28-52

Martin CL, Pielke RA (1983) The adequacy of the hydrostatic assumption in sea breeze modeling over flat terrain. J Atmos Sci 40:1472-1481 
Mastrantonio G, Viola AP, Argentini S, Fiocco Giannini L, Rossini L, Abbate G, Ocone R, Casonato M (1994) Observations of sea breeze events in Rome and the surrounding area by a network of Doppler sodars. Boundary-Layer Meteorol 71:67-80

McPherson RD (1970) A numerical study of the effect of a coastal irregularity on the sea breeze. J Appl Meteorol 9:767-777

Melas D, Kioustioukis I, Lazaridis M (2006) The impact of sea breeze on air quality in the Athens area. In: Farago L (ed) et al Advances in air pollution modelling for environmental security, vol 54. Springer, Netherlands, pp 285-295

Melas D, Ziomas IC, Klemm O, Zerefos CS (1998) Anatomy of the sea-breeze circulation in Athens area under weak large-scale ambient winds. Atmos Environ 32:2223-2237

Miao JF, Kroon LJM, Vila-Guerau de Arellano J, Holtslag AAM (2003) Impacts of topography and land degredation on the sea breeze over eastern Spain. Meteorol Atmos Phys 84:157-170

Millán MM, Mantilla E, Salvador R, Carratalá A, Sanz MJ, Alonso L, Gangoiti G, Navazo M (2000) Ozone Cycles in the western Mediterranean basin: interpretation of monitoring data in complex coastal terrain. J Appl Meteorol 39:487-508

Miller JE (1948) On the concept of frontogenesis. J Atmos Sci 5:169-171

Miller STK, Keim BD, Talbot RW, Mao H (2003) Sea breeze: structure, forecasting and impacts. Rev Geophys $41: 1 / 1-131$

Moon DA (1988) A numerical modeling investigation of the effect of convective-mesoscale interactions on the sea breeze circulation. Dissertation, University of Minnesota, Minnesota

Moroz WJ (1967) A lake breeze on the eastern shore of Lake Michigan: observations and model. J Atmos Sci 24:337-355

Molina CA, Chen D (2009) A climatological study of the influence of synoptic flows on sea breeze evolution in the Bay of Alicante (Spain). Theor Appl Climatol 96:249-260

Neumann J (1977) On the rotation rate of the direction of sea and land breezes. J Atmos Sci 32:1913-1917

Neumann J, Mahrer Y (1971) A theoretical study of the land and sea breeze circulation. J Atmos Sci 28:532542

Neumann J, Mahrer Y (1974) A theoretical study of the sea and land breezes of circular islands. J Atmos Sci 31:2027-2039

Neumann J, Mahrer Y (1975) A theoretical study of the lake and land breezes of circular lakes. Mon Weather Rev 103:474-485

Neumann J, Savijarvi H (1986) The sea breeze on a steep coast. Beitr Phys Atmos 59:375-389

Nicholls ME, Pielke RA, Cotton WR (1991) A two-dimensional numerical investigation of the interaction between sea breezes and deep convection over the Florida Peninsula. Mon Weather Rev 119:298-323

Niino H (1987) The linear theory of land, and sea breeze circulation. J Meteorol Soc Jpn 65:901-920

Noonan JA, Smith RK (1986) Sea-breeze circulations over Cape York Peninsula and the generation of Gulf of Carpentaria cloud line disturbances. J Atmos Sci 43:1679-1693

Novak DR, Colle BA (2006) Observations of multiple sea breeze boundaries during an unseasonably warm day in metropolitan New York City. Bull Am Meteorol Soc 87:169-174

Ogawa S, Sha W, Iwasaki T (2003) A numerical study of the interaction of a sea-breeze front with convective cells in the daytime boundary layer. J Meteorol Soc Jpn 81:635-651

Ohashi Y, Kida H (2002) Local circulations developed in the vicinity of both coastal and inland urban areas: A numerical study with a mesoscale atmospheric model. J Appl Meteorol 41:30-45

Ohashi Y, Kida H (2004) Local circulations developed in the vicinity of both coastal and inland urban areas. Part II: effects of urban and mountain areas on moisture transport. J Appl Meteorol 43:119-133

Ookouchi Y, Uryu M, Sawada R (1978) A numerical study of the effects of a mountain on the land and sea breeze. J Meteorol Soc Jpn 56:368-386

Ookouchi Y, Segal M, Kessler RC, Pielke RA (1984) Evaluation of soil moisture on the generation and modification of mesoscale circulation. Mon Weather Rev 112:2281-2292

Pearson RA (1973) Properties of the sea breeze front as shown by a numerical model. J Atmos Sci 30:10501060

Pearson RA, Carboni G, Brusasca G (1983) The sea breeze with mean flow. Q J Roy Meteorol Soc 109:809_ 830

Pearce RP (1955) The calculation a sea breeze circulation in terms of the differential heating across the coastline. Q J Roy Meteorol Soc 81:351-381

Porson A, Steyn DG, Schayes G (2007a) Sea breeze scaling from numerical model simulations. Part 1: pure sea breezes. Boundary-Layer Meteorol 122:17-29

Porson A, Steyn DG, Schayes G (2007b) Sea breeze scaling from numerical model simulations. Part II: interactions between the sea breeze and slope flows. Boundary-Layer Meteorol 122:31-41 
Porson A, Steyn DG, Schayes G (2007c) Formulation of an index for sea breezes in opposing winds. J Clim Appl Meteorol 46:1257-1263

Physick WL (1976) A numerical model of the sea breeze phenomenon over a lake or gulf. J Atmos Sci 33:2107-2135

Physick WL (1980) Numerical experiments on the inland penetration of the sea breeze. Q J Roy Meteorol Soc 106:735-746

Physick WL, Smith RK (1985) Observations and dynamics of sea-breezes in northern Australia. Aust Meteorol Mag 33:51-63

Pielke RA (1974a) A three-dimensional numerical model of the sea breezes over South Florida. Mon Weather Rev 102:115-139

Pielke RA (1974b) A comparison of three-dimensional and two-dimensional numerical prediction of sea breezes. J Atmos Sci 31:1577-1585

Pielke RA, Segal M (1986) Mesoscale circulations forced by differential terrain heating. In: Ray PS (ed) Mesoscale meteorology and forecasting. American Meteorological Society, Boston, pp 516-548

Plant RS, Keith GJ (2007) Occurrence of Kelvin-Helmholtz billows in sea breeze circulations. BoundaryLayer Meteorol 122:1-15

Puygrenier V, Lohou F, Campistron B, Said F, Pigeon G, Benech B, Serca D (2005) Investigation on the fine structure of sea-breeze during ESCOMPTE experiment. Atmos Res 74:329-353

Qian T, Epifanio CC, Zhang F (2009) Linear theory calculations for the sea breeze in a background wind: the equatorial case. J Atmos Sci 66:1749-1763

Ramis C, Romero R (1995) A first numerical simulation of the development and structure of the sea breeze in the island of Mallorca. Ann Geophys 13:981-994

Rao PN, Fuelberg HE (2000) An Investigation of convection behind the Cape Canaveral sea-breeze front. Mon Weather Rev 128:3437-3458

Rao PN, Fuelberg HE, Droegemeier KK (1999) High-resolution modeling of the Cape Canaveral area landwater circulations and associated features. Mon Weather Rev 127:1808-1821

Richiardone R, Pearson RA (1983) Inland convection and energy transfers in a sea breeze model. Q J Roy Meteorol Soc 109:325-338

Ries H, Schlunzen KH (2009) Evaluation of a mesoscale model with different surface parameterizations and vertical resolutions for the bay of Valencia. Mon Weather Rev 137:2646-2661

Rotunno R (1983) On the linear theory of the land and sea breeze. J Atmos Sci 40:1999-2009

Samuelsson P, Tjernstrom M (2001) Mesoscale flow modification induced by land-lake surface temperature and roughness differences. J Geophys Res 106:12419-12435

Savijarvi H (1997) Diurnal winds around Lake Tanganyika. Q J Roy Meteorol Soc 123:901-918

Savijarvi H, Alestalo M (1988) The sea breeze over a lake or gulf as the function of the prevailing flow. Beitr Phys Atmos 61:98-104

Savijarvi H, Matthews S (2004) Flow over small heat islands: a numerical sensitivity study. J Atmos Sci 61:859-868

Schlunzen KH (1990) Numerical studies on the inland penetration of sea breeze fronts at a coastline with tidally flooded mudflats. Beitr Phys Atmos 63:243-256

Segal M, Pielke RA (1985) On the effect of water temperature and synoptic flows on the development of surface flows over narrow-elongated water bodies. J Geophys Res 90:4907-4910

Segal M, Arritt R (1992) Nonclassical mesoscale circulations caused by surface sensible heat-flux gradients. Bull Am Meteorol Soc 73:1593-1604

Segal M, Mahrer Y, Pielke RA (1983) A study of meteorological patterns associated with a lake confined by mountains - the Dead Sea case. Q J Roy Meteorol Soc 109:549-564

Segal M, Avissar R, McCumber M, Pielke R (1988) Evaluation of vegetation effects on the generation and modification of mesoscale circulations. J Atmos Sci 45:2268-2293

Segal M, Purdom J, Song J, Pielke R, Mahrer Y (1986) Evaluation of cloud shading effects on the generation and modification of mesoscale circulations. Mon Weather Rev 114:1201-1212

Segal M, Leuthold M, Arritt RW, Anderson C, Shen J (1997) Small lake daytime breezes: some observational and conceptual evaluations. Bull Am Meteorol Soc 78:1135-1147

Sha W, Kawamura T, Ueda H (1991) A numerical study on sea/land breezes as a gravity current: KelvinHelmholtz billows and inland penetration of the sea-breeze front. J Atmos Sci 48:1649-1665

Sha W, Kawamura T, Ueda H (1993) A numerical study of nocturnal sea/land breezes: prefrontal gravity waves in the compensating flow and inland penetration of the sea-breeze cutoff vortex. J Atmos Sci 50:1076-1088

Sha W, Ogawa S, Iwasaki T (2004) A numerical study on the nocturnal frontogenesis of the sea breeze front. J Meteorol Soc Jpn 82:817-823 
Shaw W, Lundquist JK, Schreck S (2009) Research needs for wind resource characterization. Bull Am Meteorol Soc 90:535-538

Sheih CM, Moroz WJ (1975) Mathematical modelling of lake breeze. Atmos Environ 9:575-586

Shen J (1998) Numerical modelling of the effects of vegetation and environmental conditions on the lake breeze. Boundary-Layer Meteorol 87:481-498

Shepherd JM, Ferrier BS, Ray PS (2001) Rainfall morphology in Florida convergence zones: a numerical study. Mon Weather Rev 129:177-197

Simpson JE (1994) Sea breeze and local winds. Cambridge University Press, UK, 234 pp

Simpson JE (1997) Gravity currents: in the environment and in the laboratory. Cambridge University Press, UK, $244 \mathrm{pp}$

Simpson JE, Mansfield DA, Milford JR (1977) Inland penetration of sea-breeze fronts. Q J Roy Meteorol Soc 103:47-76

Small E, Giorgi F, Sloan L, Hostetler S (2001) The effects of dessication and climate change on the hydrology of the Aral Sea. J Clim 14:300-322

Song JL (1986) A numerical investigation of Florida's sea breeze-cumulonimbus interactions. Dissertation, Colorado State University, Colorado, U.S.A.

Srinivas CV, Venkatesan R, Singh A (2007) Sensitivity of mesoscale simulations of land-sea breeze to boundary layer turbulence parameterization. Atmos Environ 41:2534-2548

Stephan K, Kraus H, Ewenz CM, Hacker JM (1999) Sea-breeze front variations in space and time. Meteorol Atmos Phys 70:81-95

Stivari SMS, de Oliveira AP, Karam HA, Soares J (2003) Patterns of local circulation in the Itaipu Lake area: numerical simulations of lake breeze. J Appl Meteorol 42:37-50

Steyn DG (1998) Scaling the vertical structure of sea breezes. Boundary-Layer Meteorol 86:505-524

Steyn DG (2003) Scaling the vertical structure of sea breezes revisited. Boundary-Layer Meteorol 107:177188

Steyn DG, Mckendry I (1988) Quantitative and qualitative evaluation of a three-dimensional mesoscale numerical model simulation of a sea breeze in complex terrain. Mon Weather Rev 116:1914-1926

Steyn DG, Kallos G (1992) A study of the dynamics of hodograph rotation in the sea breezes of Attica, Greece. Boundary-Layer Meteorol 58:215-228

Sun J, Lenschow D, Mahrt L, Crawford TL, Davis K, Oncley SP, MacPherson JI, Wang Q, Dobosy RJ, Desjardins RL (1997) Lake-induced atmospheric circulations during BOREAS. J Geophys Res 102:2915529166

Talbot C, Augustin P, Leroy C, Willart V, Delbarre H, Khomenko G (2007) Impact of a sea breeze on the boundary-layer dynamics and the atmospheric stratification in a coastal area of the North Sea. Boundary-Layer Meteorol 125:133-154

Thompson WT, Holt T, Pullen J (2007) Investigation of a sea breeze front in an urban environment. Q J Roy Meteorol Soc 133:579-594

Tijm ABC, Van Delden AJ (1999) The role of sound waves in sea-breeze initiation. Q J Roy Meteorol Soc 125:1997-2018

Tijm ABC, Holtslag AAM, Van Delden AJ (1999a) Observations and modeling of the sea breeze with the return current. Mon Weather Rev 127:625-640

Tijm ABC, Van Delden AJ, Holtslag AAM (1999b) The inland penetration of sea breezes. Contrib Atmos Phys 72:317-328

Troen I (1982) Analytical and numerical modelling of flow driven by surface differential heating. Dissertation, University of Copenhagen, Denmark

Wakimoto RM, Atkins NT (1994) Observations of the sea-breeze front during CaPE. Part I: single-doppler, satellite, and cloud photogrammetry analysis. Mon Weather Rev 122:1092-1114

Walsh JE (1974) Sea breeze theory and applications. J Atmos Sci 31:2012-2026

Wang J, Eltahir EAB, Bras RL (1998) Numerical simulation of nonlinear mesoscale circulations induced by the thermal heterogeneities of land surface. J Atmos Sci 55:447-464

Wood R, Stromberg IM, Jonas PR (1999) Aircraft observations of sea breeze frontal structure. Q J Roy Meteorol Soc 125:1959-1995

Xian Z, Pielke RA (1991) The effects of width of land masses on the development of sea breezes. J Appl Meteorol 30:1280-1304

Yan H, Anthes RA (1987) The effect of latitude on the sea breeze. Mon Weather Rev 115:936-956

Yan H, Anthes RA (1988) The effect of variations in surface moisture on mesoscale circulation. Mon Weather Rev 116:192-208

Yang X (1991) A study of nonhydrostatic effects in idealized sea breeze systems. Boundary-Layer Meteorol 54:183-208 
Yimin M, Lyons TJ (2000) Numerical simulations of a sea breeze under dominant synoptic conditions at Perth. Meteorol Atmos Phys 73:89-103

Yoshikado H (1990) Vertical structure of the sea breeze penetrating through a large urban complex. J Appl Meteorol 29:878-891

Yoshikado H (1992) Numerical study of the daytime urban effect and its interaction with the sea breeze. J Appl Meteorol 31:1146-1164

Zhang Y, Chen YL, Schroeder TA (2005) Numerical simulations of sea breeze circulations over. Northwest Hawaii Weather Forecast 20:827-846

Zhong S, Takle ES (1993) The effects of large-scale winds on the sea-land-breeze circulations in an area of complex coastal heating. J Appl Meteorol 32:1181-1195

Zhong S, Leone JM, Tackle ES (1991) Interaction of the sea breeze with a river breeze in an area of complex coastal heating. Boundary-Layer Meteorol 56:101-139

Zhu M, Atkinson BW (2004) Observed and modelled climatology of the land-sea breeze circulation over the Persian Gulf. Int J Climatol 24:883-905 